Article

\title{
Experimental and Theoretical Study of Zirconocene-Catalyzed Oligomerization of 1-Octene
}

\author{
Ilya Nifant'ev ${ }^{1,2, *(\mathbb{D}}$, Alexander Vinogradov ${ }^{1}$, Alexey Vinogradov ${ }^{1}$, Stanislav Karchevsky ${ }^{3}$ and \\ Pavel Ivchenko ${ }^{1,2}$ (D) \\ 1 A.V. Topchiev Institute of Petrochemical Synthesis RAS, 29 Leninsky Pr., 119991 Moscow, Russia; \\ amvvin@mail.ru (A.V.); vinasora@gmail.com (A.V.); phpasha1@yandex.ru (P.I.) \\ 2 Chemistry Department, M.V. Lomonosov Moscow State University, 1 Leninskie Gory Str., Building 3, \\ 119991 Moscow, Russia \\ 3 Joint-Stock Company “Institute of Petroleum Refining and Petrochemistry", 12 Iniciativnaya Str., \\ 450065 Ufa, Republic of Bashkortostan, Russia; st_karchevsky@mail.ru \\ * Correspondence: ilnif@yahoo.com; Tel.: +7-495-939-4098
}

Received: 26 June 2020; Accepted: 15 July 2020; Published: 17 July 2020

check for updates

\begin{abstract}
Zirconocene-catalyzed coordination oligomerization of higher $\alpha$-olefins is of theoretical and practical interest. In this paper, we present the results of experimental and theoretical study of $\alpha$-olefin oligomerization, catalyzed by $\left.\left(\eta^{5}-\mathrm{C}_{5} \mathrm{H}_{5}\right)\right]_{2} \mathrm{ZrX}_{2} \mathbf{1} / \mathbf{1}^{\prime}$ and $\mathrm{O}\left[\mathrm{SiMe}_{2}\left(\eta^{5}-\mathrm{C}_{5} \mathrm{H}_{4}\right)\right]_{2} \mathrm{ZrX} \mathbf{2}_{2} \mathbf{2} / \mathbf{2}^{\prime}$ $(\mathrm{X}=\mathrm{Cl}, \mathrm{Me})$ with the activation by modified methylalymoxane MMAO-12 or by perfluoroalkyl borate $\left[\mathrm{PhNMe}{ }_{2} \mathrm{H}\right]\left[\mathrm{B}\left(\mathrm{C}_{6} \mathrm{~F}_{5}\right)_{4}\right]\left(\mathrm{NB}^{\mathrm{F}}\right)$ in the presence and in the absence of organoaluminium compounds, $\mathrm{Al}\left(\mathrm{CH}_{2} \mathrm{CHMe}_{2}\right)_{3}$ (TIBA) and/or $\mathrm{Et}_{2} \mathrm{AlCl}$. Under the conditions providing a conventional mononuclear reaction mechanism, $\mathbf{1}^{\prime}$ catalyzed dimerization with low selectivity, while $\mathbf{2}^{\prime}$ initiated the formation of oligomers in equal mass ratio. The presence of TIBA and especially $\mathrm{Et}_{2} \mathrm{AlCl}$ resulted in an increase of the selectivity of dimerization. Quantum chemical simulations of the main and side processes performed at the M-06x/ DGDZVP level of the density functional theory (DFT) allowed to explain experimental results involving traditional mononuclear and novel $\mathrm{Zr}-\mathrm{Al}_{1}$ and $\mathrm{Zr}-\mathrm{Al}_{2}$ mechanistic concepts.
\end{abstract}

Keywords: coordination polymerization; density functional theory; methylenealkanes; $\alpha$-olefins; oligomerization; zirconocenes

\section{Introduction}

Zirconocenes hold a significant position among single-site catalysts of $\alpha$-olefin polymerization due to high catalytic activity, excellent copolymerization homogeneity, and wide boundaries of regioand sterecontrol [1-6]. Even in recent years, many of the studies of the reaction mechanisms [7-10] and structure-activity relationships [11-16] for these catalysts were performed using a generally accepted cationic concept (Scheme 1A) based on the fundamental research of Cossee and Arlman [17-26].

It is known that zirconocene dichloride $\left(\eta^{5}-\mathrm{C}_{5} \mathrm{H}_{5}\right)_{2} \mathrm{ZrCl}_{2}$ (1, Scheme 1B) [27-30], disubstituted zirconocenes $\left(\eta^{5}-\mathrm{RC}_{5} \mathrm{H}_{4}\right)_{2} \mathrm{ZrCl}_{2}$ [31-35], ansa-zirconocenes $\mathrm{Z}\left(\eta^{5}-\mathrm{C}_{5} \mathrm{H}_{4}\right)_{2} \mathrm{ZrCl}_{2}$ (where $\mathrm{Z}$ is oneor two-membered bridge between cylopentadienyl rings) [36,37], and thiapentalene zirconium complex [38] catalyze the oligomerization of $\alpha$-olefins $\mathrm{RCH}=\mathrm{CH}_{2}$ with a formation of the mixtures of methylenealkanes and higher oligomers (Scheme 1B). For 1, this reaction results in selective formation of methylenealkanes ( $D P_{n}=2$, Scheme $\left.1 \mathrm{~B}\right)$ in the presence of a minor excess of methylaluminoxane (MAO). Christoffers and Bergman [28,29] demonstrated that chloride is an indispensable component of the catalyst system that provides the high selectivity of dimerization. Their observation was confirmed experimentally by an increase of the selectivity of zirconocene/MAO catalyzed dimerization in the 
presence of $\mathrm{R}_{2} \mathrm{AlCl}[30,39]$. SiOSi-bridged zirconium complex 2 (Scheme 1B) demonstrated the best performance in terms of catalytic activity and $\alpha$-olefin dimer yield $[36,40]$.

(A)

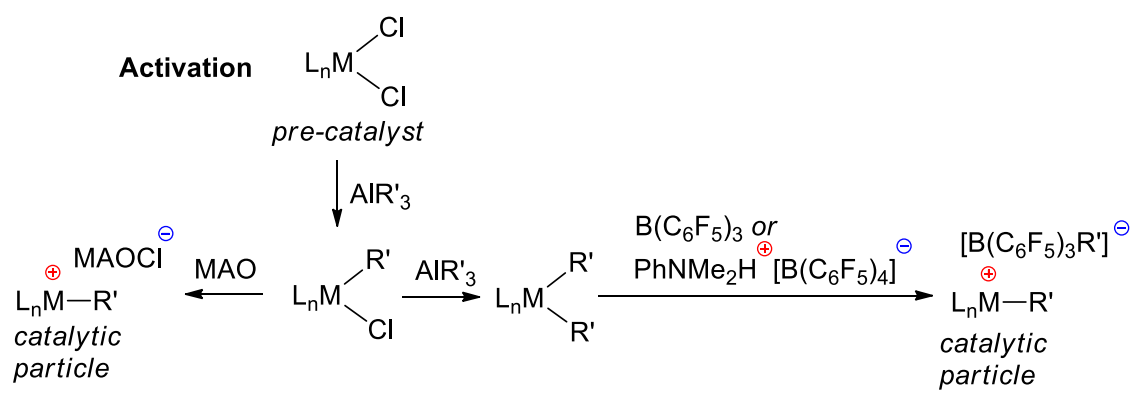

\section{Polymerization/termination}

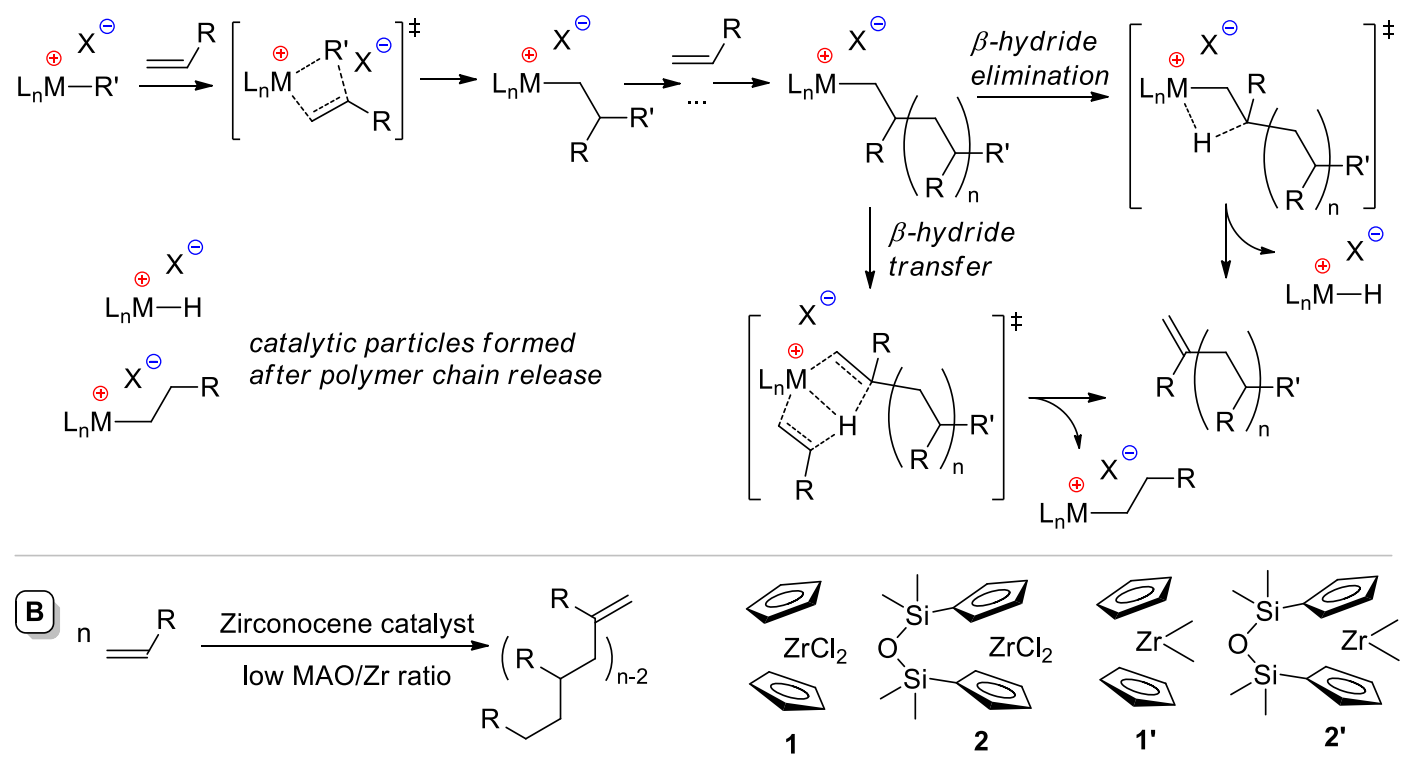

Scheme 1. (A) Cossee-Arlman polymerization mechanism. (B) $\alpha$-Olefin dimerization, pre-catalysts of selective $\alpha$-olefin dimerization $(\mathbf{1}, \mathbf{2})$ and pre-catalysts studied in this work $\left(\mathbf{1}^{\prime}, \mathbf{2}^{\prime}\right)$.

In the early 1990s, zirconocene-catalyzed oligomerization of higher $\alpha$-olefins had been considered as a particular case of single-site polymerization, keeping in mind that, at higher MAO/Zr ratios, 1 and its analogs catalyzed the formation of lower oligomers and matched the Flory distribution in full compliance with traditional cationic mononuclear coordination-insertion concept presented in Scheme 1A $[10,38,41]$. However, in recent years, the coordination oligomerization of higher $\alpha$-olefins has attracted the major attention of researchers because of the importance of this process for the synthesis of hydrogenated oligomers of $\alpha$-olefins (in most cases, 1-decene) which are high quality polyolefin oil basestocks (PAOs). Such oligomerization provides the high structural homogeneity of the oligomers, but requires abandoning the high $\mathrm{Al} / \mathrm{Zr}$ ratios in a catalytic system to suppress monomer transfer to $\mathrm{Al}$ [38]. Thus, the task of a more thorough investigation of the $\alpha$-olefin oligomerization in the presence of minimal amounts of organoaluminium compounds became relevant again.

In this paper, we report the results of the experimental study of 1-octene oligomerization using zirconocenes $\mathbf{1}$ and $\mathbf{2}$ and their dimethyl derivatives $\mathbf{1}^{\prime}$ and $\mathbf{2}^{\prime}$ (Scheme 1B), activated by modified methylalymoxane MMAO-12 and perfluoroalkyl borate $\left[\mathrm{PhNMe}_{2} \mathrm{H}\right]\left[\mathrm{B}_{(}\left(\mathrm{C}_{6} \mathrm{~F}_{5}\right)_{4}\right]\left(\mathrm{NB}^{\mathrm{F}}\right)$ with and without organoaluminium components and molecular hydrogen. The express purpose of the study was to compare the impact of different activators (MMAO- 12 or $\mathrm{NB}^{\mathrm{F}}$ ), trialkylaluminium (TIBA), $\mathrm{R}_{2} \mathrm{AlCl}$, and $\mathrm{H}_{2}$ on the reaction rate, oligomer distribution, and molecular structure of the reaction products. In addition, we tried to interpret and visualize the results of the oligomerization experiments using the density functional theory (DFT) modeling of the possible reaction pathways to extend the 
mechanistic insights of single-site polymerization mechanism within and beyond the commonly accepted Cossee-Arlman coordination-insertion mechanism.

\section{Materials and Methods}

\subsection{General Experimentsl Remarks}

TIBA (1 M solution in hexane, Merck, Kenilworth, NJ, USA), MMAO-12 (1.52 M solution in toluene, Merck, NJ, USA), $\left(\eta^{5}-\mathrm{C}_{5} \mathrm{H}_{5}\right)_{2} \mathrm{ZrCl}_{2}$ (Merck, NJ, USA), [PhNMe $\left.2 \mathrm{H}\right]\left[\mathrm{B}\left(\mathrm{C}_{6} \mathrm{~F}_{5}\right)_{4}\right]$ (Fischer Scientific, Waltham, MA, USA), $d$-solvents $\mathrm{C}_{6} \mathrm{D}_{6}$ and $\mathrm{CDCl}_{3}\left(99.8 \%{ }^{2} \mathrm{H}\right.$, Cambridge Isotope Laboratories, Inc., Tewksbury, MA, USA) were used as purchased. Further, 1-Octene (Merck, NJ, USA) was stored over $\mathrm{Na}$ wire and distilled under argon. SiOSi-bridged zirconocene dichloro complex 2 [42] and $\left(\eta^{5}-\mathrm{C}_{5} \mathrm{H}_{5}\right)_{2} \mathrm{ZrMe}_{2} \mathbf{1}^{\prime}$ [43] (Scheme 1) were synthesized according to previously reported procedures.

The ${ }^{1} \mathrm{H}$ NMR spectra were recorded on a Bruker AVANCE 400 spectrometer $(400 \mathrm{MHz}$, Bruker, Billerica, MA, USA) at $20{ }^{\circ} \mathrm{C}$. The chemical shifts are reported in ppm relative to the solvent residual peaks (7.26 ppm). Elemental analysis was performed on a Perkin Elmer Series II CHNS/O Analyzer 2400 (Perkin Elmer, Inc., Waltham, MA, USA). The distribution of oligomers produced in zirconocene-catalyzed reactions was measured by the gas chromatography (GC) method. GC analysis was carried out with a KRISTALL-2000M gas chromatograph (Meta-chrom Ltd., Yoshkar-Ola, Russia) equipped with a SolGel-1ms $(60 \mathrm{~m} \times 0.25 \mathrm{~mm} \times 0.25 \mu \mathrm{m})$ column and a flame ionization detector. Helium was used as a carrier gas at a rate of $1.364 \mathrm{cc} / \mathrm{min}$ and with a split ratio of 73.3:1. The injection temperature was $320^{\circ} \mathrm{C}$, and the column temperature was $200{ }^{\circ} \mathrm{C}$ within $5 \mathrm{~min}$ and then increased from 200 to $300^{\circ} \mathrm{C}$ at a rate of $10^{\circ} \mathrm{C} / \mathrm{min}$.

\subsection{Synthesis of Zirconocene $2^{\prime}$}

Zirconocene dichloro complex $2(2.12 \mathrm{~g}, 5 \mathrm{mmol})$ was suspended in $50 \mathrm{~mL}$ of ether, cooled to $-40{ }^{\circ} \mathrm{C}$, and LiMe $(11 \mathrm{~mL}$ of $1 \mathrm{M}$ solution in ether, $1 \mathrm{mmol})$ was added dropwise. The mixture was allowed to warm to the room temperature, the solution was filtered off and evaporated. The residue was recrystallized from $n$-hexane, the colorless crystals of $\mathbf{2}^{\prime}$ were dried in vacuo. The yield was $3.13 \mathrm{~g}(82 \%)$. For $\mathrm{C}_{16} \mathrm{H}_{26} \mathrm{OSi}_{2} \mathrm{Zr}$ calculated $\mathrm{C}, 50.34 ; \mathrm{H}, 6.86 ; \mathrm{O}, 4.19$. Found: $\mathrm{C}, 50.38 ; \mathrm{H}, 6.89 ; \mathrm{O}, 4.21$. ${ }^{1} \mathrm{H}$ NMR $\left(\mathrm{C}_{6} \mathrm{D}_{6}, 20^{\circ} \mathrm{C}\right) \delta: 6.27\left(\mathrm{dd},{ }^{3} J=6.06 \& 6.32 \mathrm{~Hz}, 4 \mathrm{H}\right) ; 6.01\left(\mathrm{dd},{ }^{3} J=6.06 \& 6.32 \mathrm{~Hz}, 4 \mathrm{H}\right) ; 0.22$ $(\mathrm{s}, 12 \mathrm{H}) ;-0.05(\mathrm{~s}, 6 \mathrm{H}) .{ }^{13} \mathrm{C}$ NMR $\left(\mathrm{C}_{6} \mathrm{D}_{6}, 20^{\circ} \mathrm{C}\right) \delta: 117.53 ; 117.22 ; 112.97 ; 30.41 ; 0.97$. For NMR spectra, see Section $\mathrm{S} 2$ in the Supporting Information.

\subsection{Oligomerization Experiments}

Briefly, 1-Octene $(15.7 \mathrm{~mL}, 100 \mathrm{mmol}), n$-decane (internal standard, $1 \mathrm{~mL})$, and TIBA (1 mL of $1 \mathrm{M}$ solution in hexane, $1 \mathrm{mmol}$ ) were placed in three-necked flask, prefilled with argon. Then zirconocene precatalyst $(0.05 \mathrm{mmol})$ was added. After maintaining the external bath at $60^{\circ} \mathrm{C}$ for $5 \mathrm{~min}$, the given volume of MMAO-12 (1.2M solution in toluene) or $\mathrm{NB}^{\mathrm{F}}(40 \mathrm{mg}, 0.05 \mathrm{mmol})$ was added. After $2 \mathrm{~h}$ of stirring, the mixture was cooled, and $2 \mathrm{~mL}$ of saturated aqueous solution of $\mathrm{Na}_{2} \mathrm{CO}_{3}$ was added. The sample of the organic fraction was analyzed by NMR spectroscopy and GC.

\subsection{DFT Calculations}

The initial cartesian coordinates of the stationary points had been found by PRIRODA program (version 4.0, Moscow, Russia) [44] using the $3 \zeta$ basis. The final optimization and determination of the thermodynamic parameters for stationary points and transition states were carried out using Gaussian 09 program [45] for gas phase at $298.15 \mathrm{~K}$. The M-06x functional [46] and DGDZVP basis [47,48] were used in the optimizations. As demonstrated earlier, M-06x functional is one of the most correct for calculations of the free energies in the DFT modeling of zirconocene-catalyzed reactions [49]. Transition states were found by energy scanning with sequential changing of key geometric parameters 
with a step of $0.01 \AA$ followed by Berny optimization. DFT calculations data are provided in the Supporting Information.

\section{Results and Discussion}

\subsection{Oligomerization Experiments and End-Group Analysis}

To compare the catalytic activities and mechanisms of the chain termination events, we studied four types of pre-catalysts, namely, zirconocene dichloride $\mathbf{1}$, its dimethyl derivative $\mathbf{1}^{\prime}$, SiOSi-bridged dichloro 2, and dimethyl $2^{\prime}$ ansa-complexes (Scheme 1B). MMAO-12 and $\mathrm{NB}^{\mathrm{F}}$ were used as activators. TIBA was added as an additional activator in most of the experiments (Table 1). The reactions were carried out in liquid 1-octene media (see Section 2.3 for experimental details), and the low values of the degree of oligomerization $D P_{n}$ simplified the end-group identification by the analysis of ${ }^{1} \mathrm{H}$ NMR spectra of the reaction mixtures and oligomer fractions. The basic principles of the similar end-group analysis were summarized in our recent publication [50], based on previous research of $\alpha$-olefin polymerization [51-56]. NMR spectra were accompanied by the results of GC analysis and compared with the recent results of Kissin [10]. The weight distribution of the reaction products taking into account unreacted 1-octene is presented in Figure 1.

Table 1. Results of 1-octene oligomerization experiments.

\begin{tabular}{|c|c|c|c|c|c|c|c|c|c|c|}
\hline \multirow[t]{2}{*}{ Run } & \multirow[t]{2}{*}{$\begin{array}{l}\text { Pre- } \\
\text { cat. }\end{array}$} & \multirow[t]{2}{*}{$\begin{array}{l}\text { TiBA/Zr } \\
\text { Ratio }\end{array}$} & \multirow[t]{2}{*}{ Activator } & \multirow{2}{*}{$\begin{array}{l}\text { [Act]/ } \\
\text { [Precat] } \\
\text { Ratio }\end{array}$} & \multirow[t]{2}{*}{$\mathbf{H}_{2}$} & \multirow[t]{2}{*}{$\begin{array}{c}\text { Conv. } \\
\%\end{array}$} & \multicolumn{4}{|c|}{$\begin{array}{c}\text { Dimer (C16), Trimer (C24), Tetramer } \\
\text { (C32) and Pentamer (C40) wt. \% in } \\
\text { the Products }\end{array}$} \\
\hline & & & & & & & C16 & $\mathrm{C} 24$ & $\mathrm{C} 32$ & $\mathrm{C} 40$ \\
\hline 1 & 1 & 20 & MMAO-12 & 10 & - & 85 & 88.8 & 9.2 & 2.1 & - \\
\hline 2 & 1 & 20 & $\begin{array}{c}\text { MMAO-12 +1 eq. } \\
\mathrm{Et}_{2} \mathrm{AlCl}\end{array}$ & 10 & - & 74 & 90.3 & 7.8 & 1.9 & - \\
\hline 3 & 1 & 20 & MMAO-12 & 10 & 1 bar & 84 & 92.0 & 6.7 & 1.3 & - \\
\hline 4 & 1 & 20 & MMAO-12 & 200 & - & 68 & 77.6 & 15.1 & 5.4 & 1.9 \\
\hline 5 & 1 & 20 & $\mathrm{NB}^{\mathrm{F}}$ & 1 & - & 53 & 81.6 & 13.2 & 4.2 & 1.0 \\
\hline 6 & 1 & 20 & $\mathrm{NB}^{\mathrm{F}}$ & 1 & 1 bar & 70 & 84.6 & 11.6 & 3.3 & 0.5 \\
\hline 7 & $\mathbf{1}^{\prime}$ & - & MMAO-12 & 10 & - & 47 & 88.7 & 8.6 & 2.6 & - \\
\hline 8 & $\mathbf{1}^{\prime}$ & - & $\begin{array}{c}\text { MMAO-12 +1 eq. } \\
\mathrm{Et}_{2} \mathrm{AlCl}\end{array}$ & 10 & - & 60 & 93.4 & 5.6 & 1.0 & - \\
\hline 9 & $\mathbf{1}^{\prime}$ & - & $\mathrm{NB}^{\mathrm{F}}$ & 1 & - & 14 & 78.2 & 17.7 & 4.0 & - \\
\hline 10 & $\mathbf{1}^{\prime}$ & 20 & $\mathrm{NB}^{\mathrm{F}}$ & 1 & - & 8 & 75.2 & 18.9 & 5.8 & - \\
\hline 11 & $\mathbf{1}^{\prime}$ & - & $\mathrm{NB}^{\mathrm{F}}+1$ eq. $\mathrm{Et}_{2} \mathrm{AlCl}$ & 1 & - & 7 & 90.7 & 8.2 & 1.0 & - \\
\hline 12 & $1^{\prime}$ & 20 & $\mathrm{NB}^{\mathrm{F}}$ & 1 & 1 bar & 18 & 72.3 & 16.8 & 9.2 & 1.7 \\
\hline 13 & 2 & 20 & MMAO-12 & 10 & - & 82 & 92.4 & 7.1 & 0.5 & - \\
\hline 14 & 2 & 20 & $\begin{array}{c}\text { MMAO-12 +1 eq. } \\
\mathrm{Et}_{2} \mathrm{AlCl}\end{array}$ & 10 & - & 79 & 96.3 & 3.5 & 0.2 & - \\
\hline 15 & 2 & 20 & MMAO-12 & 10 & 1 bar & 86 & 92.3 & 7.2 & 0.5 & - \\
\hline 16 & 2 & 20 & MMAO-12 & 200 & - & 70 & 78.1 & 15.8 & 5.7 & 0.4 \\
\hline 17 & 2 & 20 & $\mathrm{NB}^{\mathrm{F}}$ & 1 & - & 68 & 67.7 & 23.3 & 7.6 & 1.4 \\
\hline 18 & 2 & 20 & $\mathrm{NB}^{\mathrm{F}}$ & 1 & 1 bar & 85 & 82.2 & 13.6 & 3.4 & 0.8 \\
\hline 19 & $2^{\prime}$ & - & MMAO-12 & 10 & - & 65 & 58.4 & 25.1 & 11.5 & 5.0 \\
\hline 20 & $2^{\prime}$ & - & $\begin{array}{c}\mathrm{MMAO}-12+1 \text { eq. } \\
\mathrm{Et}_{2} \mathrm{AlCl}\end{array}$ & 10 & - & 57 & 87.6 & 11.2 & 1.2 & - \\
\hline 21 & $2^{\prime}$ & - & $\mathrm{NB}^{\mathrm{F}}$ & 1 & - & 60 & 25.2 & 25.2 & 22.9 & 26.7 \\
\hline 22 & $2^{\prime}$ & 20 & $\mathrm{NB}^{\mathrm{F}}$ & 1 & - & 13 & 47.4 & 21.7 & 15.6 & 15.2 \\
\hline 23 & $2^{\prime}$ & - & $\mathrm{NB}^{\mathrm{F}}+1$ eq. $\mathrm{Et}_{2} \mathrm{AlCl}$ & 1 & - & 38 & 70.3 & 22.1 & 6.3 & 1.3 \\
\hline 24 & $2^{\prime}$ & - & $\mathrm{NB}^{\mathrm{F}}$ & 1 & $1 \mathrm{bar}$ & 73 & 48.3 & 26.0 & 14.6 & 11.1 \\
\hline
\end{tabular}

The first experiment (Table 1, Run 1) was performed using 1-octene after activation of zirconocene dichloride 1 by 20 eq. TIBA and 10 eq. MMAO-12. The results of the experiment were in good agreement with the results of Christoffers and Bergman [28,29], and previously reported data for oligomerization of 1-hexene in the presence of $\mathbf{1}$, activated by TIBA and 10 eq. MAO [36,40]. The main product of the reaction was 7-methylenepentadecane, and the $\mathrm{C}_{16}$ fraction contained $\sim 3 \%$ each of the products with $-\mathrm{CH}=\mathrm{CH}-$ and $>\mathrm{C}=\mathrm{CH}$ - structural fragments. The first fragment represents linear hexadecenes formed by the secondary 1-octene insertion to $\mathrm{Cp}_{2} \mathrm{Zr}-n-\mathrm{C}_{8} \mathrm{H}_{17}$ species followed by 
$\beta$-hydride elimination or $\beta$-hydride transfer. The formation of the products with $>\mathrm{C}=\mathrm{CH}$ - fragment can be attributed to intermediate formation of allyl intermediates [55] or to 1,2-rearrangement of the primary alkyl intermediate proposed by Crowther et al. [51,56]. In view of the fact that this reaction was carried out in the absence of molecular hydrogen, the latter explanation appeared to be more realistic, and we evaluated its feasibility by the DFT calculations (see Section 3.2.1).
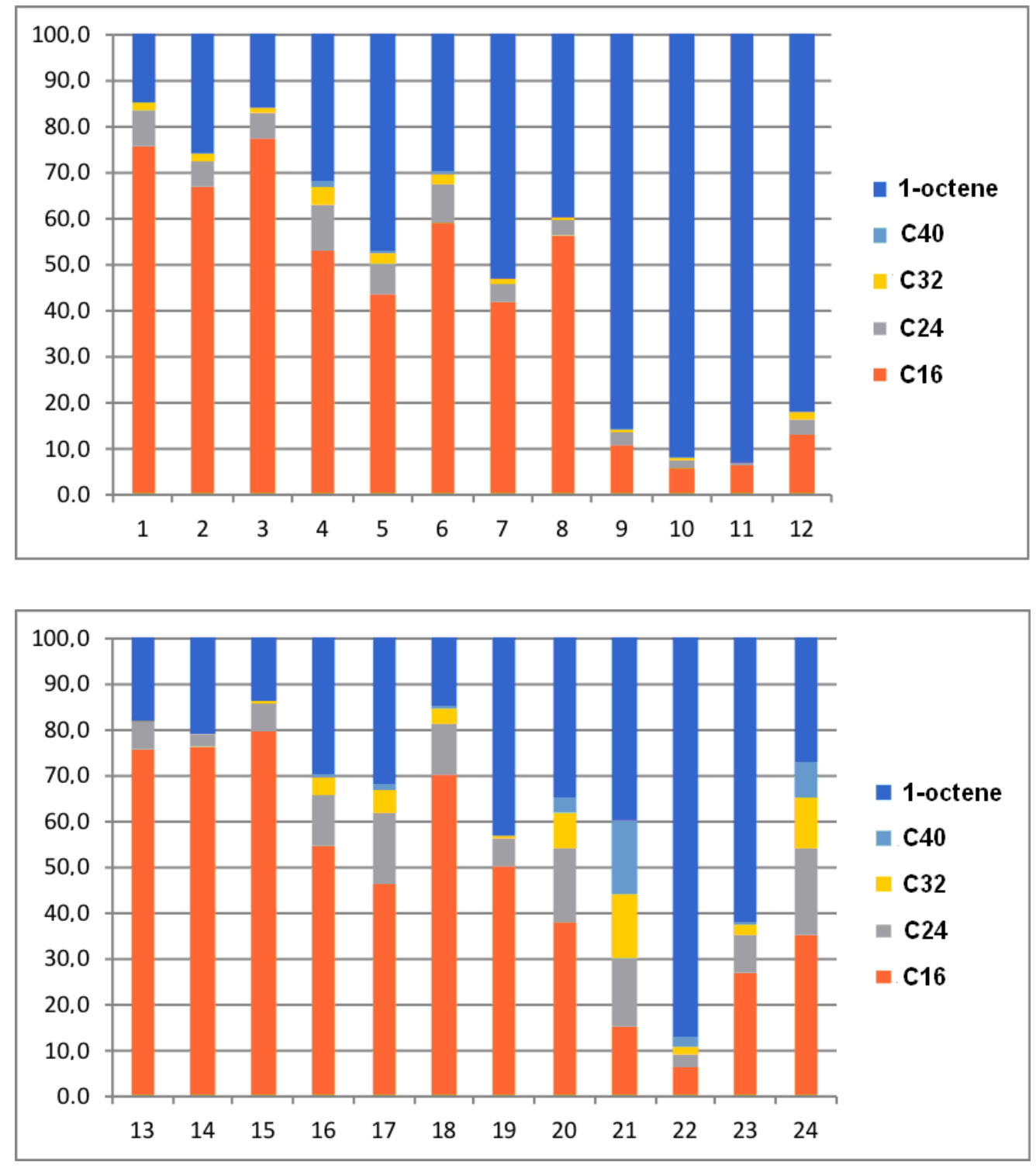

Figure 1. The weight distribution of the reaction products and unreacted 1-octene in bulk oligomerization, catalyzed by $\mathbf{1} / \mathbf{1}^{\prime}$ (top) and $\mathbf{2} / \mathbf{2}^{\prime}$ (bottom). Run numbers are given below the x-axes.

In the presence of $\mathrm{Et}_{2} \mathrm{AlCl}$ (Table 1, Run 2), the selectivity of the formation of 7-methylenepentadecane increased, with low decrease in catalytic activity. It is of critical importance that the formation of the isomers of 7-methylenepentadecane containing $>\mathrm{C}=\mathrm{CH}$ - fragment was significantly reduced. In the presence of the molecular hydrogen (Table 1, Run 3), we detected an increase of the selectivity of dimerization in comparison with Run 1 (Table 1), and the presence of the side products with $>\mathrm{C}=\mathrm{CH}$ - fragment was also negligible. When $200 \mathrm{eq}$. MMAO-12 was used (Table 1, Run 4), the selectivity of the dimer formation was lower, and the content of the products with $-\mathrm{CH}=\mathrm{CH}-$ fragments was slightly increased. 
Replacement of MMAO- 12 by NB ${ }^{\mathrm{F}}$ in experiments with zirconocene 1 pre-treated by TIBA (Table 1 , Runs 5 and 6) resulted in significant reduction of the catalytic activity. In terms of the selectivity of dimer formation, the results of these experiments were closely related with the results of 1-octene oligomerization in the presence of 200 eq. MMAO-12, but the formation of side products was lower. Therefore, the use of $\mathrm{NB}^{\mathrm{F}}$ instead of MAO seems feasible in terms of the yield of structurally uniform $\alpha$-olefin oligomers. Note that it is this activation method that was used in prospective technologies of the production of PAOs [57-64].

In experiments with dimethyl derivative $\mathbf{1}^{\prime}$ activated by 10 eq. MMAO-12 in the absence and in the presence of $\mathrm{Et}_{2} \mathrm{AlCl}$ (Table 1, Runs 7 and 8), the catalytic activity was lower, but the selectivity of dimerization was substantially higher in comparison with Runs 1 and 2. The result of Rin 7 is somewhat inconsistent with the prior assertion that the presence of chlorides is essential to provide the selectivity of $\alpha$-olefin dimerization $[28,29,36,40]$.

Activation of $\mathbf{1}^{\prime}$ by $\mathrm{NB}^{\mathrm{F}}$ (Table 1, Run 9) resulted in a slow formation of the mixture of oligomers. The addition of TIBA (Table 1, Run 10) or $\mathrm{Et}_{2} \mathrm{AlCl}$ (Table 1, Run 11) slowed the reaction rate. Even so, the presence of $\mathrm{Et}_{2} \mathrm{AlCl}$ provided the high selectivity of the dimer formation without any side reactions! The presence of the molecular hydrogen (Table 1, Run 12) in experiment with $\mathrm{NB}^{\mathrm{F}}$ activation of $\mathbf{1}^{\prime}$ did not affect the product distribution, but slightly accelerated the reaction. However, it must be noted that, in the presence of $\mathrm{H}_{2}$ the signals of $>\mathrm{C}=\mathrm{CH}$ - were detected (these signals were fully absent for Runs 10 and 11).

Being activated by 20 eq. TIBA and 10 eq. MMAO-12, zirconocene 2 catalyzed the selective dimerization of 1-octene (Table 1, Run 13), and the addition of 1 eq. $\mathrm{Et}_{2} \mathrm{AlCl}$ increased the selectivity of dimerization (Table 1, Run 14) in accordance with previously published results [36]. The reaction mixtures contained minimal amounts of the product with internal $-\mathrm{CH}=\mathrm{CH}-$ double bond, $>\mathrm{C}=\mathrm{CH}-$ fragments were absent. The presence of the molecular hydrogen (Table 1, Run 15) resulted in modest acceleration of the reaction, with the appearance of the $>\mathrm{C}=\mathrm{CH}-$ signals. In the presence of $200 \mathrm{eq}$. MMAO-12 (Table 1, Run 16), we detected increasing of the higher oligomer content, lower amounts of $-\mathrm{CH}=\mathrm{CH}-$ products, and significant $(\sim 8 \%)$ formation of the products containing $>\mathrm{C}=\mathrm{CH}$ - fragment. When 2 was activated by TIBA and $\mathrm{NB}^{\mathrm{F}}$ (Table 1, Run 17), $>\mathrm{C}=\mathrm{CH}-$ signals were not detected, this signal appeared in the presence of the molecular hydrogen (Table 1, Run 18).

Dimethyl derivatives $\mathbf{1}^{\prime}$ and $\mathbf{2}^{\prime}$ demonstrated qualitatively different behavior being activated by MMAO-12 (Table 1, Runs 7 and 19, respectively). SiOSi-bridged dimethyl complex turned out to be the catalyst of the oligomerization in contrast with $\mathbf{1}^{\prime}$ that was moderately selective dimerization catalyst. The addition of $\mathrm{Et}_{2} \mathrm{AlCl}$ (Table 1, Run 20) led to increasing of the selectivity of dimerization. The fundamental difference in catalytic behavior between $\mathbf{1}^{\prime}$ and $\mathbf{2}^{\prime}$ was detected in experiments with $\mathrm{NB}^{\mathrm{F}}$ activator: $\mathbf{2}^{\prime}$ in the presence of 1 eq. of perfuoroaryl borate (Table 1, Run 21) catalyzed the formation of oligomers in parity by weight. The addition of 20 eq. TIBA (Table 1, Run 22) resulted in a shift to the preference of the dimer formation with a slowing down of the reaction, and the addition of $\mathrm{Et}_{2} \mathrm{AlCl}$ (Table 1, Run 23) slightly increased both reaction rate and dimerization selectivity. The influence of the molecular hydrogen (Table 1, Run 24) was insignificant.

\subsection{DFT Modeling of the Reaction Pathways for $\left(\eta^{5}-\mathrm{C}_{5} \mathrm{H}_{5}\right)_{2} \mathrm{Zr}$-Based Catalytic Species}

Despite the fact that complex 1 was historically the first pre-catalyst used in zirconocene polymerization, only a few works devoted to the oligomerization of higher $\alpha$-olefins in the presence of 1, activated by MAO [27-31,36-40,65-67] or (perfluorophenyl)borates [68], have been published to date. The recent investigation of Kissin [10] comprised a comprehensive analysis of the products of 1-hexene oligomerization, catalyzed by 1/MAO at high $\mathrm{Zr}$ :Al ratios ( 1:200). The use of a large excess of MAO in the experiments of Kissin obviously resulted in the formation of significant amounts of the $\mathrm{C}_{7}, \mathrm{C}_{13}$, and $\mathrm{C}_{19}$ products of 1-hexene oligomerization, initiated by $\mathrm{Cp}_{2} \mathrm{ZrMe}^{+}$species. In our experiments, the percentage of such products was expected as null and void. In addition, when TIBA was used as an organoaluminium activator, $C_{12}$ and $C_{20}$ reaction products were not detected 
in the reaction mixtures. In experiments with dimethyl derivatives $\mathbf{1}^{\prime}$ and $\mathbf{2}^{\prime}$, the contribution of $\mathrm{C}_{9}, \mathrm{C}_{17}$, and $\mathrm{C}_{25}$ reaction products was also negligible. All the above allowed us to stay focused on the processes involving the hydride catalytic species formed after the activation of zirconocenes, and $\mathrm{C}_{8}, \mathrm{C}_{16}$, and $\mathrm{C}_{24}$ derivatives that are the products of the insertion of 1-octene. In this section, we discuss the reaction mechanism with the involvement of the results of the modeling using the density functional theory (DFT) at M06-2X/DGDZVP [46-49] level. Optimized geometries, cartesian coordinates, and energy parameters for all stationary points and transition states mentioned below are presented in the Supporting Information.

\subsubsection{Mononuclear Reaction Mechanism}

In our calculations, we used 1-butene as a model olefin. In the framework of the traditional mechanism of zirconocene-catalyzed polymerization of $\alpha$-olefins, catalytic species represent a $\mathrm{Cp}_{2} \mathrm{Zr}$-alkyl cationic complexes. First, we optimized the different conformations of $\left[\left(\eta^{5}-\mathrm{C}_{5} \mathrm{H}_{5}\right)_{2} \mathrm{Zr}-n-\mathrm{Bu}\right]^{+}$and $\left[\left(\eta^{5}-\mathrm{C}_{5} \mathrm{H}_{5}\right)_{2} \mathrm{Zr}-\mathrm{sec}-\mathrm{Bu}\right]^{+}$and found that $\beta$-agostic $n$-butyl complex $\mathbf{I}-\mathbf{2} \mathbf{p} \beta$ (Scheme 2, here and below index $p$ means "primary") had the minimal free energy. Additional stabilization of sec-alkyl complexes I-2s $\beta$ and I-2s $\beta \beta$ (here and below s-"secondary") by hyperconjugation, proposed by Kissin [10], was not confirmed by our calculations. The free energy of primary alkyl $\alpha$-agostic I-2p $\alpha$ and $\gamma$-agostic I-2p $\gamma$ complexes were 10 and $4 \mathrm{kcal} / \mathrm{mol}$ higher than $\mathrm{I}-2 \mathrm{~s} \beta$, which rules out these complexes from further consideration.

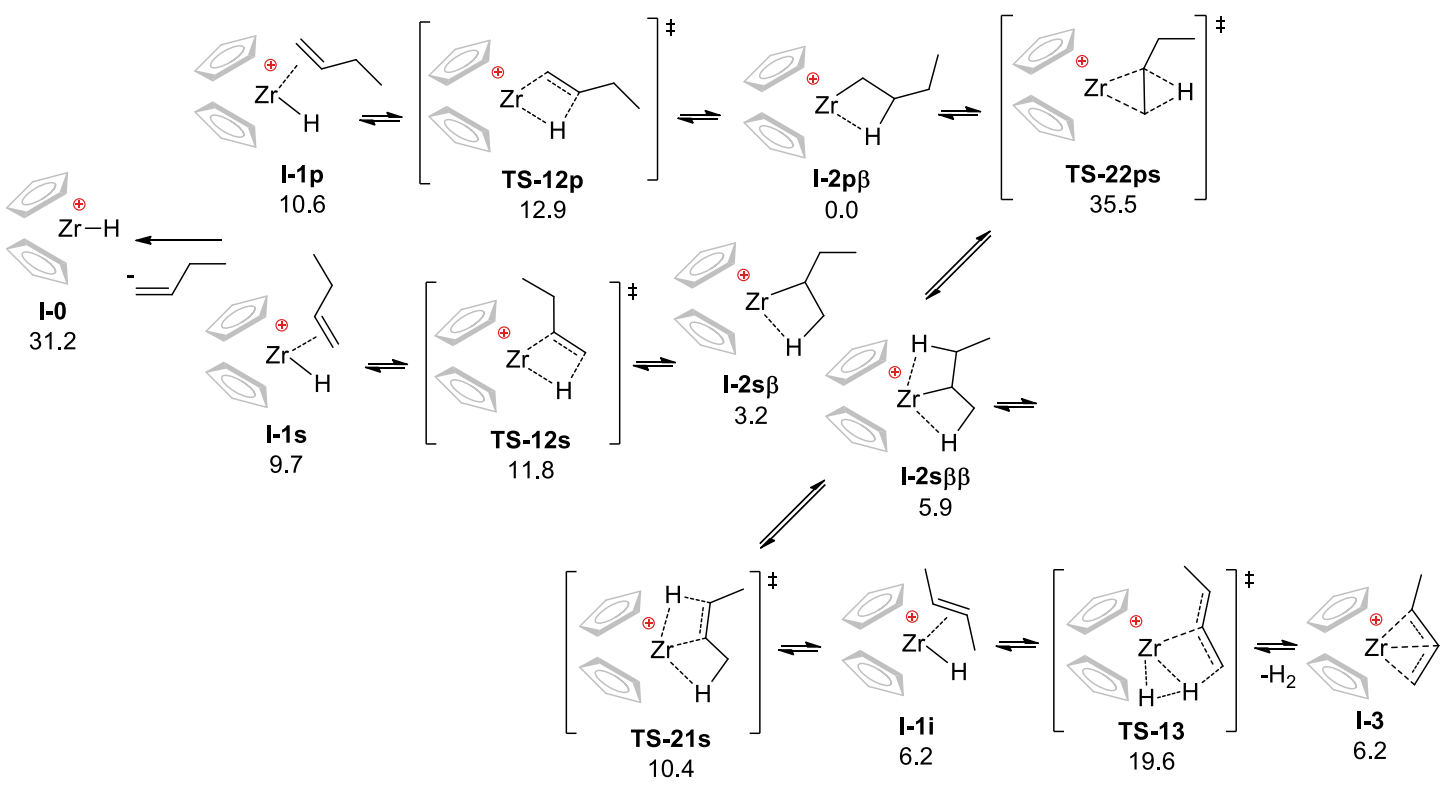

Scheme 2. The first group of the transformations of zirconocene butyl and isobutyl cationic complexes: the reactions in the absence of the second molecule of 1-butene. The values of calculated free energies $(\mathrm{kcal} / \mathrm{mol})$ relative to $\mathbf{I}-\mathbf{2} \mathbf{p} \boldsymbol{\beta}$ are given.

The $\beta$-agostic alkyl complexes can be involved in different processes (Scheme 2). The first reaction is $\beta$-hydride elimination resulting in zirconocene hydride cation with $\pi$-coordinated olefin molecule. Depending on the type of the complex (primary or secondary) and position of $\beta$-agostic hydrogen in butyl fragment, this reaction may result in different products via transition states that are also diverse in their energy. For $\left[\left(\eta^{5}-\mathrm{C}_{5} \mathrm{H}_{5}\right)_{2} \mathrm{Zr} \text {-sec-Bu }\right]^{+}, \beta$-hydride elimination with a formation of $(E)$-2-butene complex I-1i was found to be preferable in comparison with the formation of 1-butene complex I-1s. The activation barrier for $\beta$-hydride elimination in $\mathbf{I}-2 \mathbf{p} \beta$ with the formation of 1-butene complex I-1p was the highest (Scheme 2). In view of the reversibility of the processes presented in Scheme 2, the results of calculations contradicted the common concept that postulates the preference of the olefin insertion with a formation of the primary alkyl complex. However, this claim is true for the insertion 
of $\alpha$-olefin molecule in $\mathrm{Zr}$-alkyl complexes (see below), and the reaction seems to be more complex at the stage of the insertion of the first olefin molecule at $\mathrm{Zr}-\mathrm{H}$ bond. First, the formation of $\mathbf{I}-\mathbf{1 p}$ and I-1s via $\beta$-hydride elimination is energetically unfavorable, the formation of naked hydride cation I-0 seems impossible. This allows us to exclude I-0, I-1, and TS-12 from the list of actual catalytic species. However, in light of the study of the subsequent processes, the possibility of intramolecular rearrangement between primary $\mathbf{I}-\mathbf{2} \mathbf{p}$ and secondary I-2s alkyl complexes should be considered. We optimized the structure of the corresponding transition state TS-22ps (Scheme 2, Figure 2, left) and found that $\Delta \mathrm{G}^{\neq}$for this reaction is $35.5 \mathrm{kcal} / \mathrm{mol}$. Such a value is too high for freely occurrence of such rearrangement. Another possible process is a formation of allyl complex I-3 from I-1i via TS-13 (Scheme 2, Figure 2, right). The activation barrier for this reaction is only $13.4 \mathrm{kcal} / \mathrm{mol}$. Therefore, the formation of the allyl species should not be excluded in the detailed analysis of the chemical behavior of cationic zirconocene alkyl complexes. Note that the formation of allyl complexes in the zirconocene-catalyzed polymerization of $\alpha$-olefins was proven experimentally in a number of publications [55,69-75].
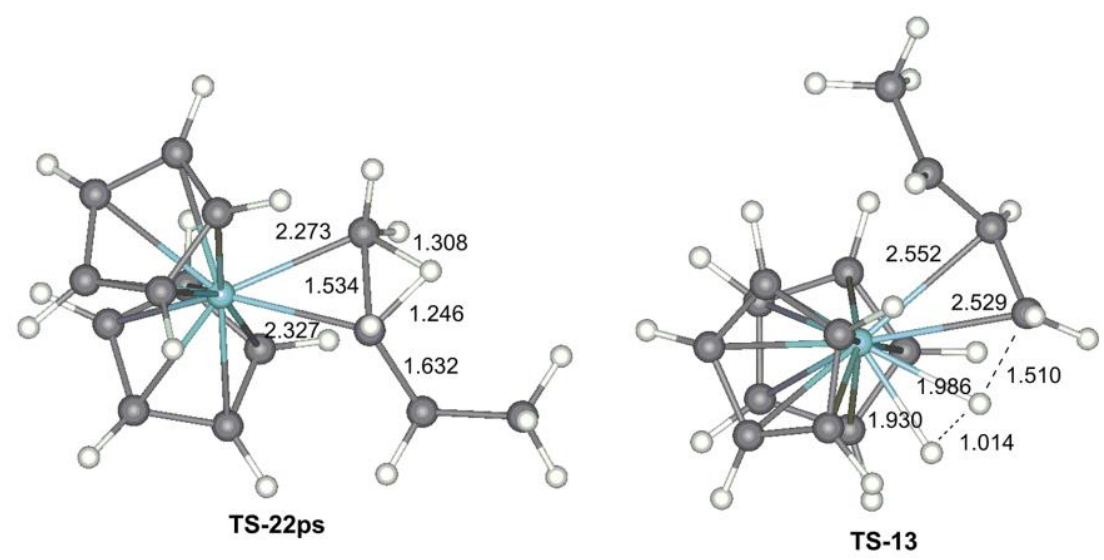

Figure 2. Optimized geometries of the transition states TS-22ps and TS-13.

Given the instability of cationic hydride complexes in the framework of a mononuclear mechanism, we decided to focus on the processes involving alkyl zirconocene cations and 1-butene molecule. At the first stage, $\pi$-complexes of different structures I-4 can be formed (Scheme 3 ). This process is exergonic, the relative energies of $\pi$-complexes are dependent on the nature of $\mathrm{Zr}$-alkyl ( $n$-butyl or sec-butyl) and orientation of the coordinated 1-butene molecule. Optimized geometries and energy parameters of these structures are presented in the Supporting Information, the most stable structure I-4pp corresponds to a "head to head" direction of the subsequent polymerization (1,2-insertion of the monomer in primary alkyl complex) in line with the conventional reaction mechanism. The values of the relative free energies (Scheme 3) of the corresponding transition states TS-45 (Figure 3) clearly indicate the preference of the primary insertion. The experimental estimation of the rates of primary and secondary insertions of 1-hexene made by Kissin $\left(k_{\mathrm{prim}} / k_{\mathrm{sec}} \sim 2000\right)$ [10] is in line with the results of our calculations $\left(k_{\text {prim }} / k_{\mathrm{sec}} \sim 3000\right.$ based on TS-45pp and TS-45ps values under equal Arrhenius factors). Thus, the main pathway of the insertion of the second 1-butene molecule results in the formation of branched primary alkyl complex I-5pp.

Another possible way of the transformations of $\mathbf{I}-\mathbf{4}$ is $\beta$-hydride transfer. The free activation energies TS-44 (Scheme 3) for these processes were found to be substantially higher in comparison with TS-45, the energy of degenerate process TS-44pp was only $3 \mathrm{kcal} / \mathrm{mol}$ lower in comparison with TS-44ps resulting in the formation of $\pi$-complex of sec-butyl substituted zirconocene I-4sp (Scheme 3 ). Isomeric TS-44sp results in the formation of 2-butene $\pi$-complex I-4pi. This relatively small difference between TS-44pp and TS-44sp helps to explain the formation of 2-alkenes in the zirconocene-catalyzed oligomerization of $\alpha$-olefins. 
So, the main direction of the reaction of $\left[\left(\eta^{5}-\mathrm{C}_{5} \mathrm{H}_{5}\right)_{2} \mathrm{Zr}-n-\mathrm{Bu}\right]^{+}$with 1-butene was the formation of the relatively stable $\beta$-agostic complex I-5pp $\beta$. This intermediate can undergo $\beta$-hydride elimination via TS-56pp, and coordination of the second 1-butene molecule with a formation of $\pi$-complex I-7pp $\beta$. The latter can undergo $\beta$-hydride transfer via TS-78ppp to form a more stable $\pi$-complex I-8pp $\beta$ or coordination-insertion of the 1-butene molecule via transition state TS-89ppp with a formation of branched alkyl complex I-9ppp (Scheme 4). These reactions are key processes for the estimation of the selectivity of dimerization, the subject of our study. The values of the free activation energy for all three possible processes are close, therefore in the frameworks of the mononuclear mechanism the chain release (dimer formation) and chain propagation are possible. The question of the chain release mechanism remains open, however. The free energy of alkyl $\pi$-complex I-8ppp is $15 \mathrm{kcal} / \mathrm{mol}$ lower in comparison with hydride $\pi$-complex I-6pp, thus confirming the conventional wisdom that $\beta$-hydride transfer is a main pathway of the chain release for mononuclear mechanism [10].

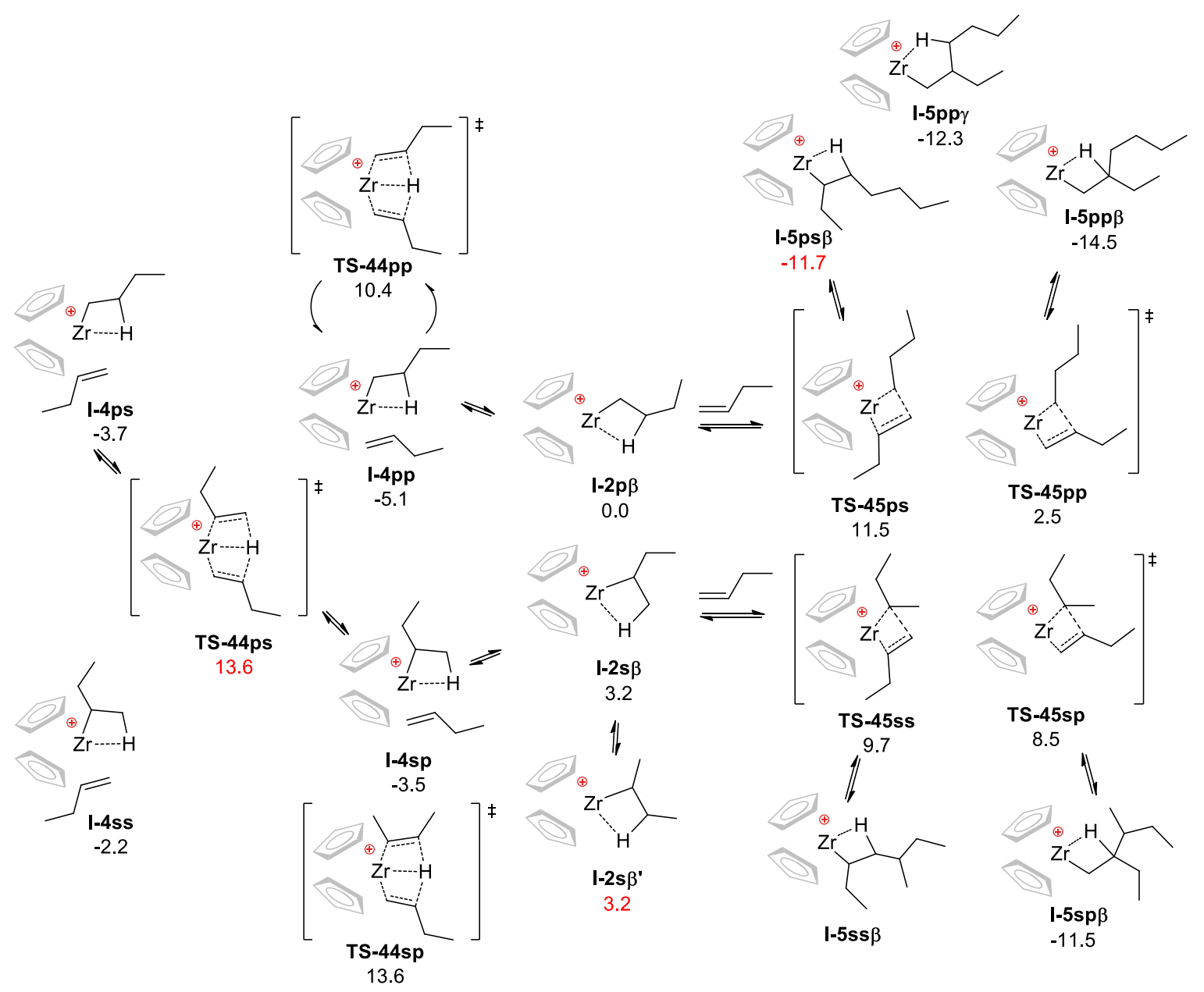

Scheme 3. Transformations of zirconocene butyl and isobutyl cationic complexes with the participance of the second molecule of 1-butene. The values of calculated free energies ( $\mathrm{kcal} / \mathrm{mol})$ relative to I-2p $\beta$ are given.

The DFT modeling of the competition between chain release and chain propagation after the second $\alpha$-olefin insertion predicted the possibility of the formation of higher oligomers. However, the experiments on 1-octene oligomerization under conditions providing a cationic mononuclear mechanism (Table 1, Runs 4, 9) demonstrated the preference of the dimerization. In terms of the analysis of the energy reaction profiles, this contradiction can be explained by the assumption of a significant difference of the Arrhenius pre-exponential factors for chain termination (TS for $\beta$-hydride elimination and $\beta$-hydride transfer are based on stable $\beta$-agostic complex) and chain propagation 
(TS based on high-energy $\alpha$-agostic complex). Note that direct transformation of I-5pp $\beta$ to I-5pp $\alpha$ without the participance of the $\alpha$-olefin molecule (Scheme 4) requires more than $15 \mathrm{kcal} / \mathrm{mol}$ in $\mathrm{G}$ scale.

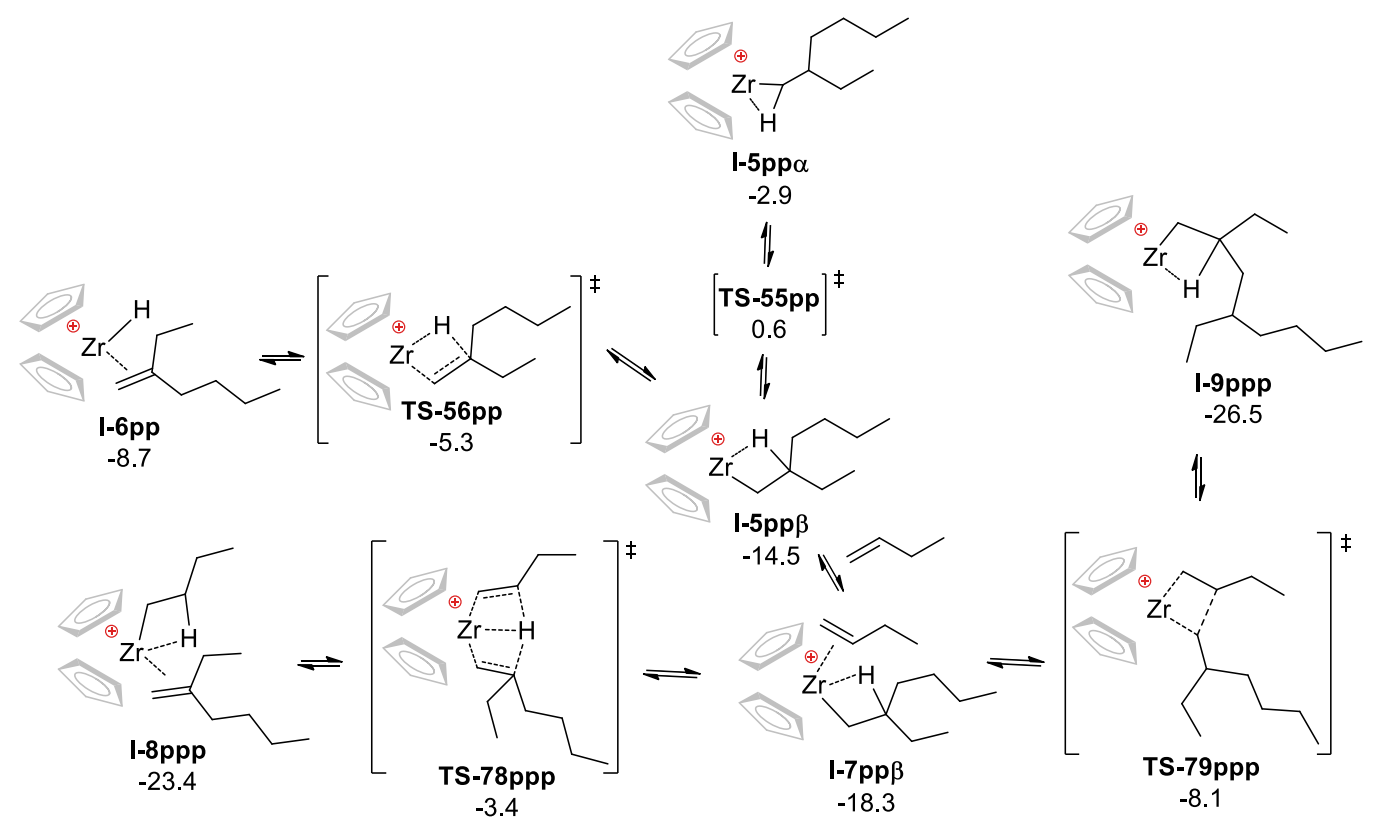

Scheme 4. Transformations of $\beta$-agostic complex I-5pp $\beta$. The values of calculated free energies $(\mathrm{kcal} / \mathrm{mol})$ relative to $\mathrm{I}-2 \mathrm{p} \beta$ are given.

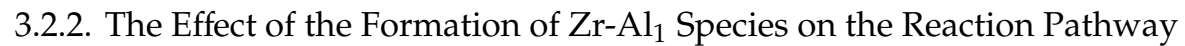

The formation of zirconium-aluminium heterometallic complexes in the reaction of zirconocenes with organoaluminium compounds is a well-known and proven fact [76-87]. In our previous works $[36,40]$ we proposed that the increasing of the selectivity of dimerization of $\alpha$-olefins can be attributed to direct participance of $\mathrm{R}_{2} \mathrm{AlCl}$ in the formation of the $\mathrm{Zr}-\mathrm{Al}_{1}$ species prone to $\beta$-hydride elimination. The idea of such assistance was emerged by Hessen et al. for zwitterionic zirconocenes [88]. Very recently, we performed comparative DFT modeling of propylene dimerization catalyzed by $\left(\eta^{5}-\mathrm{C}_{5} \mathrm{H}_{5}\right)_{2} \mathrm{Zr}(\mu-\mathrm{H})(\mu-\mathrm{X}) \mathrm{AlR}_{2}(\mathrm{X}=\mathrm{H}, \mathrm{Cl}, \mathrm{Me})$ [65]. The results of our calculations predicted the preference of $\beta$-hydride elimination after the second insertion of propylene molecule in these bimetallic species for $\mathrm{X}=\mathrm{H}$ and $\mathrm{Cl}$. Such a preference was attributed to $\mathrm{Zr}-\mathrm{Al}$ cooperative effect in binuclear complexes (Scheme 5). The modeling of the reactions of higher $\alpha$-olefins using propylene as a monomer needed to be clarified, and in the present work we report the results of DFT calculations for the key stage of 1-butene dimerization, namely $\mathrm{Me}_{2} \mathrm{AlX}$-assisted $\beta$-hydride elimination $(X=\mathrm{H}, \mathrm{Cl})$ after the insertion of the second molecule of 1-butene. Assuming that the coordination of $\mathrm{Me}_{2} \mathrm{AlX}$ (I-5pp $\beta-\mathrm{X}$, I-5pp $\alpha-X)$ and 1-butene (I-7pp $\beta)$ are reversible and competing, we optimized the structures of the key stationary points and transition states and compared the relative free energies of these species (Scheme 5).

The significant difference between propylene [65] and 1-butene (this work) was detected. Our calculations demonstrate the extremely high stability of the $\alpha$-agostic complex I-5pp $\alpha-H(-5.6 \mathrm{kcal} / \mathrm{mol})$ in comparison with $\beta$-agostic $\mathbf{I}-5 \mathbf{p p} \beta-\mathbf{H}$ which is the stage preceding the transition state of the dimer formation TS-56-H. Therefore, "pure" hydride $\mathrm{Zr}-\mathrm{Al}$ complex should not be highly active. On the other hand, for the complex formed with $\mathrm{Me}_{2} \mathrm{AlCl}$, the relative stability of the intermediates I-5 was found to be inverse: the difference in free energies between $5 \mathrm{pp} \alpha-\mathrm{Cl}$ and $\mathbf{I}-5 \mathrm{pp} \beta-\mathrm{Cl}$ was $1.2 \mathrm{kcal} / \mathrm{mol}$. Thus, the coordination of $\mathrm{R}_{2} \mathrm{AlCl}$ should promote $\beta$-hydride elimination via a low-energy intermediate and lower energy transition state, the calculated difference of the free energies of TS-79ppp and TS-56-Cl was $2.3 \mathrm{kcal} / \mathrm{mol}$. 
To evaluate the thermodynamics of the further reaction, we calculated the free energies of the $\pi$-complexes of $\left(\eta^{5}-\mathrm{C}_{5} \mathrm{H}_{5}\right)_{2} \mathrm{Zr}(\mu-\mathrm{H})(\mu-\mathrm{X}) \mathrm{AlMe}_{2}$ species with 1-butene (Scheme 5) and found that replacement of 3-methyleneheptane (I-6pp-X) by 1-butene (I-1p-X) is energetically favorable process for $\mathrm{X}=\mathrm{Cl}(-2.2 \mathrm{kcal} / \mathrm{mol})$.

At first sight, the simple model presented in Scheme 5 can explain the fact of the increasing of the selectivity of dimerization in the presence of $\mathrm{R}_{2} \mathrm{AlCl}$ species (Table 1, Runs 1-6, 8, 11). However, cationic binuclear $\mathrm{Zr}-\mathrm{Al}_{1}$ species (except well-known and inert $\left(\eta^{5}-\mathrm{C}_{5} \mathrm{H}_{5}\right)_{2} \mathrm{Zr}(\mu-\mathrm{Me})_{2} \mathrm{AlMe}_{2}$ [89-96]) were not detected in significant amounts in the reaction mixtures obtained by the reaction of zirconocene with $\mathrm{AlR}_{3}$ in the presence of MAO or perfluoroaryl borates. Moreover, NMR spectra indicated the presence of $\mathrm{Zr}-\mathrm{Al}_{2}$ complexes [97-99]. This does not mean that cationic $\mathrm{Zr}^{-\mathrm{Al}_{1}}$ species could not participate zirconocene-catalyzed oligomerization. However, our theoretical research of the possible reaction pathways would be incomplete without the analysis of the direct participation of $\mathrm{Zr}-\mathrm{Al}_{2}$ species in zircononcene-catalyzed dimerization and polymerization.

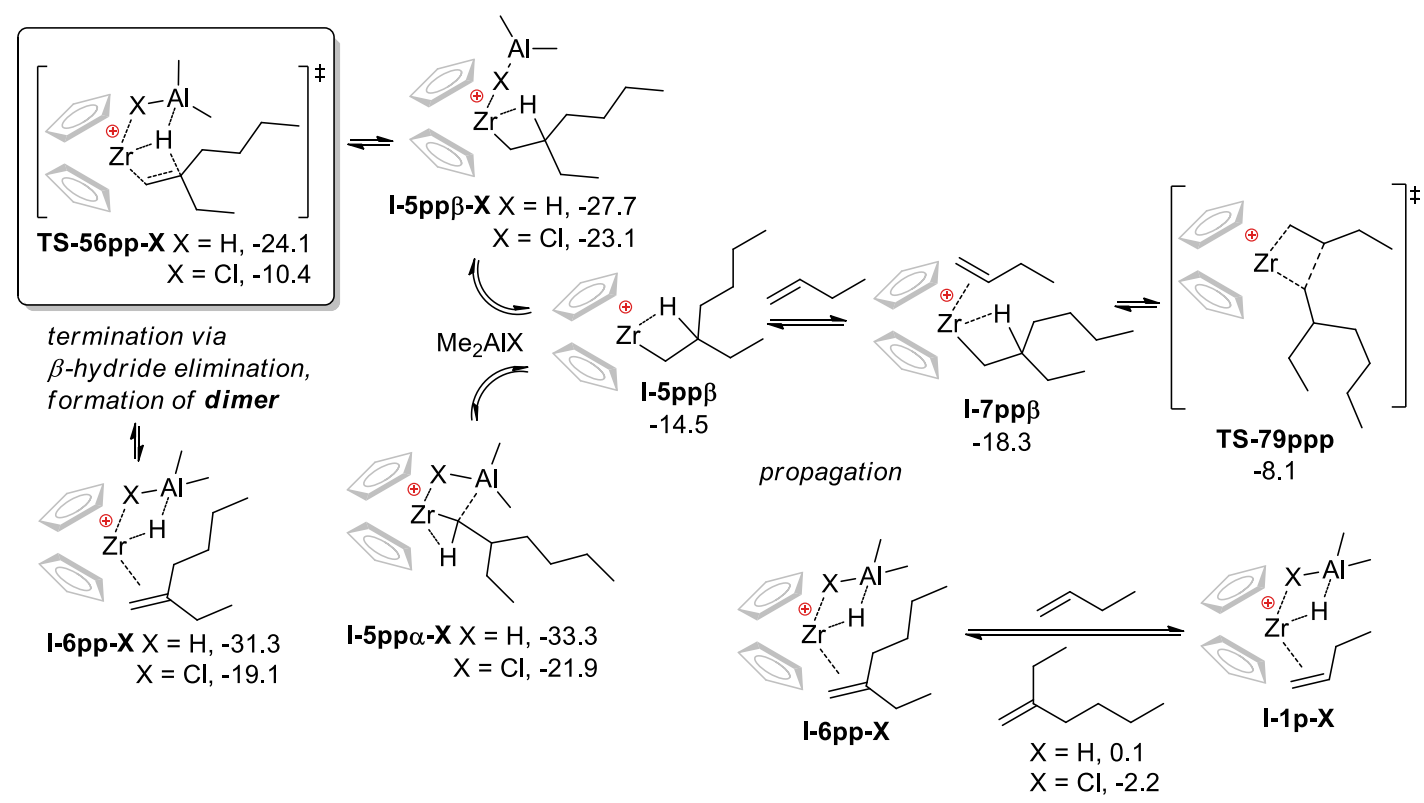

Scheme 5. Transformations of $\beta$-agostic complex I-5pp $\beta$ with the participance of $\mathrm{Me}_{2} \mathrm{AlX}$ species. The values of calculated free energies $(\mathrm{kcal} / \mathrm{mol})$ relative to $\mathbf{I}-2 \mathbf{p} \beta$ are given.

\subsubsection{Theoretical Analysis of the Possible Participation of $\mathrm{Zr}-\mathrm{Al}_{2}$ Species}

Trinuclear $\mathrm{Zr}^{-\mathrm{Al}_{2}}$ cationic complexes have been identified among the products of the reactions of zirconocene dichlorides with an excess of TIBA or diisobutyl aluminum hyrdide (DIBAL-H) [97-99]. These species (Figure 3, Scheme 6a) represent resting states of the oligomerization which were seen as unconducive to $\pi$-bonding with $\alpha$-olefin molecules due to the coordination saturation of the $\mathrm{Zr}$ atom [97]. At the first stage of the modeling, we analyzed the relative stability of the experimentally detected stable species I-0-HX and hypothetically "opened" complexes that are capable of $\pi$-bonding with $\alpha$-olefin. The calculated differences in free energies of the "opened" complexes and I-0-HX (Scheme 6a) exceeded the value of $15 \mathrm{kcal} / \mathrm{mol}$. Coordination of 1-butene with a formation of I-1-HX (Scheme 6a, Figure 3) was found to be endergonic process, thus confirming high stability of I-0-HX.

Another DFT probe of the evaluation of the possible role of $\mathrm{Zr}^{-\mathrm{Al}_{2}}$ species was in comparison of the relative energies of the stationary points and transition states, formed by I-5pp $\beta$ and $\mathrm{Me}_{2} \mathrm{Al}(\mu-\mathrm{H})(\mu-\mathrm{X}) \mathrm{AlMe}_{2}$ (Scheme $6 \mathrm{~b}$ ), with the energies of dinuclear $\mathrm{Zr}-\mathrm{Al}_{1}$ and mononuclear species (Scheme 5). Trinuclear transition states TS-56pp-HX are aesthetically beautiful (Figure 3, for animation file see the Supporting Information), and it might be tempting to assume that these TS are involved in dimerization. However, the results of our calculations demonstrate that the coordination of 
$\mathrm{Me}_{2} \mathrm{Al}(\mu-\mathrm{H})(\mu-\mathrm{X}) \mathrm{AlMe}_{2}$ is weak, and therefore, bearing in mind the difference of orders of magnitude between the concentrations of $\alpha$-olefin and organoaluminum component, the participance of such species in the catalytic process is unlikely.

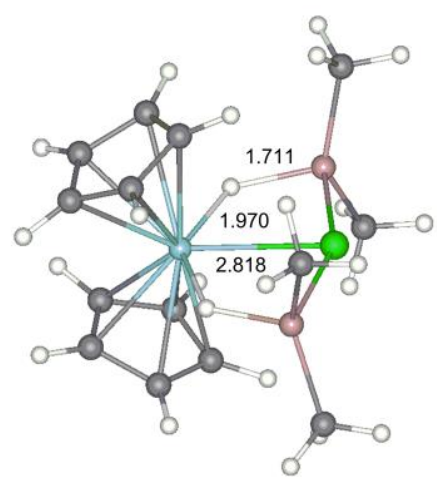

$\mathrm{I}-\mathbf{0}-\mathrm{HCl}$

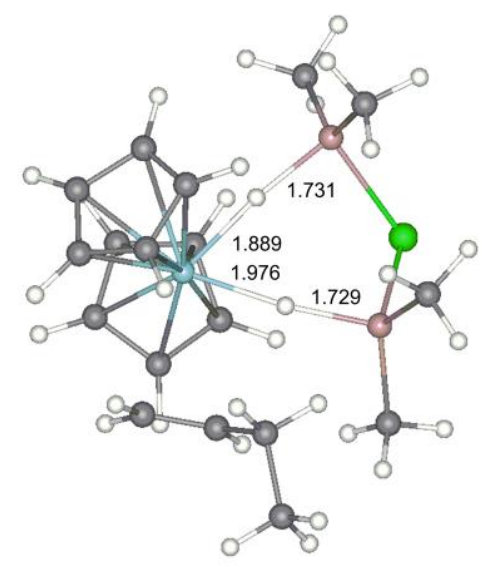

$\mathrm{I}-1-\mathrm{HCl}$

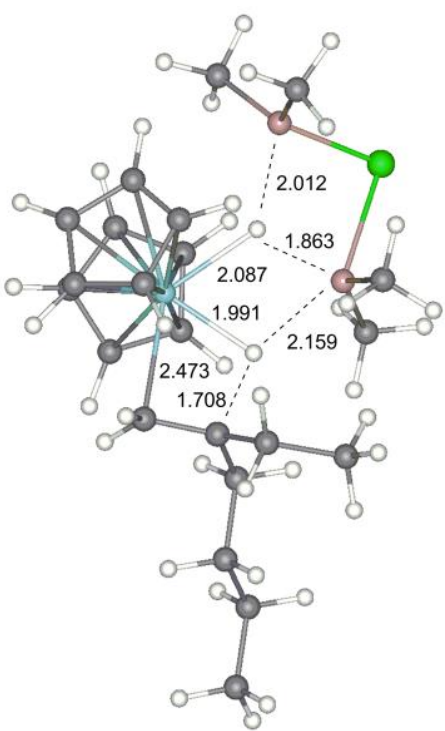

TS-56-HCI

Figure 3. Optimized geometries of the stationary points I-0-HCl (left), I-1-HCl (center) and transition state TS-56-HCl (right).

(a)

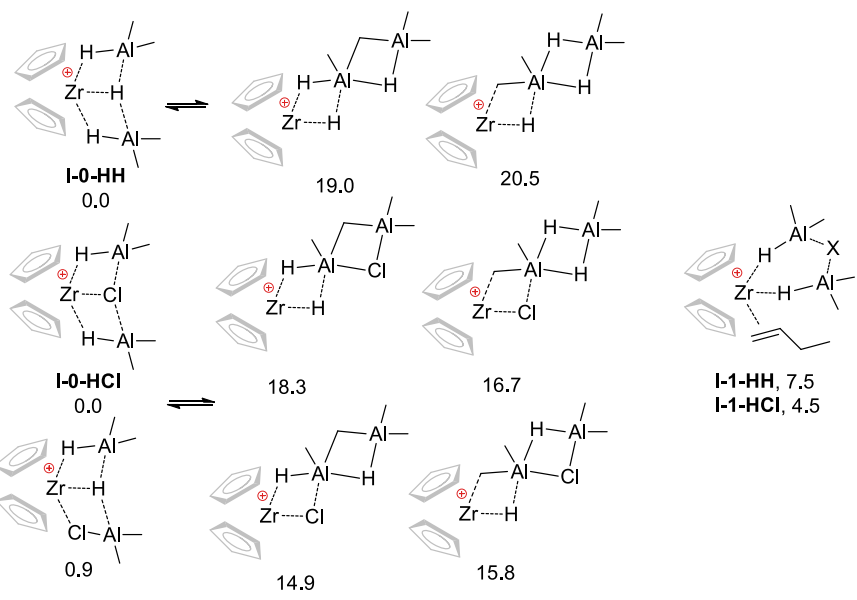

(b)
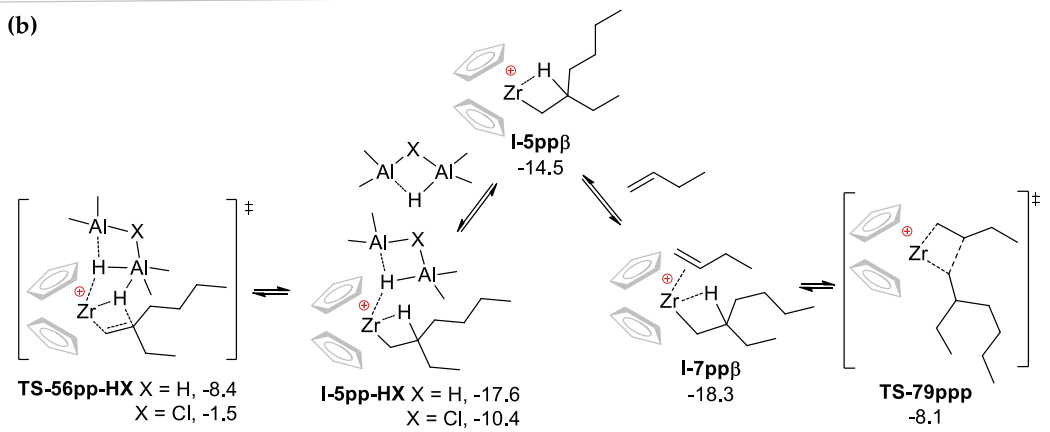

Scheme 6. Relative free energies of $\mathrm{Zr}$-Al2 species (a); transformations of $\beta$-agostic complex I-5pp $\beta$ with the participance of $\mathrm{Me}_{2} \mathrm{Al}(\mu-\mathrm{H})(\mu-\mathrm{X}) \mathrm{AlMe}_{2}$ species. The values of calculated free energies $(\mathrm{kcal} / \mathrm{mol})$ relative to $\mathbf{I}-\mathbf{2} \mathbf{p} \boldsymbol{\beta}$ are given $(\mathbf{b})$. 


\subsection{DFT Modeling of the Reaction Pathways for O[SiMe $\left.2\left(\eta^{5}-C_{5} H_{4}\right)\right]_{2} \mathrm{Zr}$-Based Catalytic Species}

The key factor of the difference between $\left.\left(\eta^{5}-\mathrm{C}_{5} \mathrm{H}_{5}\right)\right]_{2} \mathrm{Zr}$-and $\mathrm{O}\left[\mathrm{SiMe}_{2}\left(\eta^{5}-\mathrm{C}_{5} \mathrm{H}_{4}\right)\right]_{2} \mathrm{Zr}$-based catalytic systems is the ability of the bridged oxygen to coordinate $\mathrm{Zr}$ atom. Additionally, the non-symmetrical structure of the $\mathrm{O}\left[\mathrm{SiMe}_{2}\left(\mathrm{\eta}^{5}-\mathrm{C}_{5} \mathrm{H}_{4}\right)\right]_{2} \mathrm{Zr}$ implies greater variability of the ligand environment, which made it difficult to perform exhaustive DFT modeling. In our research, we only optimized the molecular structures of the most significant stationary points and transition states for $\mathrm{O}\left[\mathrm{SiMe}_{2}\left(\eta^{5}-\mathrm{C}_{5} \mathrm{H}_{4}\right)\right]_{2} \mathrm{Zr}$-based species.

The energy gain due to $\mathrm{Zr}-\mathrm{O}$ bonding can be estimated by the value of $\sim 9 \mathrm{kcal} / \mathrm{mol}$ (the difference of the free energies of I-2p $\beta$-c-anti and I-2p $\beta$, Scheme $7 a$. Such a significant difference inevitably affects the energies of the stationary points and transition states for the key stage of the reaction (Scheme $7 \mathrm{~b}$ ). The activation energy for $\beta$-hydride elimination, assisted by $\mathrm{Zr}-\mathrm{O}$ coordination (TS-56pp-c-syn), shown in Scheme $7 \mathrm{~b}$, is relatively low, but this process results in high-energy intermediate I-6pp-c-syn, dissociation of this complex with a formation of hydride I-0 requires more than $32 \mathrm{kcal} / \mathrm{mol}$ and therefore seems improbable. Our attempt to optimize the structure of the $\pi$-complex I-6pp-c-anti failed, but we found that this complex transformed into I-5pp-c-anti spontaneously.

The coordination of the third 1-butene molecule (I-7ppp) is endergonic, but exothermic process $(\Delta \mathrm{G}=8.5 \mathrm{kcal} / \mathrm{mol}, \Delta \mathrm{H}=-1.3 \mathrm{kcal} / \mathrm{mol})$, and the following chain propagation (TS-79ppp) is preferable by the value of $\sim 8 \mathrm{kcal} / \mathrm{mol}$ in comparison with chain termination via $\beta$-hydride transfer (TS-78ppp). Note that the free activation energy of the chain propagation for SiOSi-bridged complex 2 ( $15.6 \mathrm{kcal} / \mathrm{mol}$ ) is formally $\sim 3 \mathrm{kcal} / \mathrm{mol}$ lower in comparison with zirconocene 1 . Hence, in the absence of organoaluminum compounds, the SiOSi-bridged ansa-complex should catalyze oligomerization of $\alpha$-olefins. Such chemical behavior was observed experimentally (Table 1, Run 22).

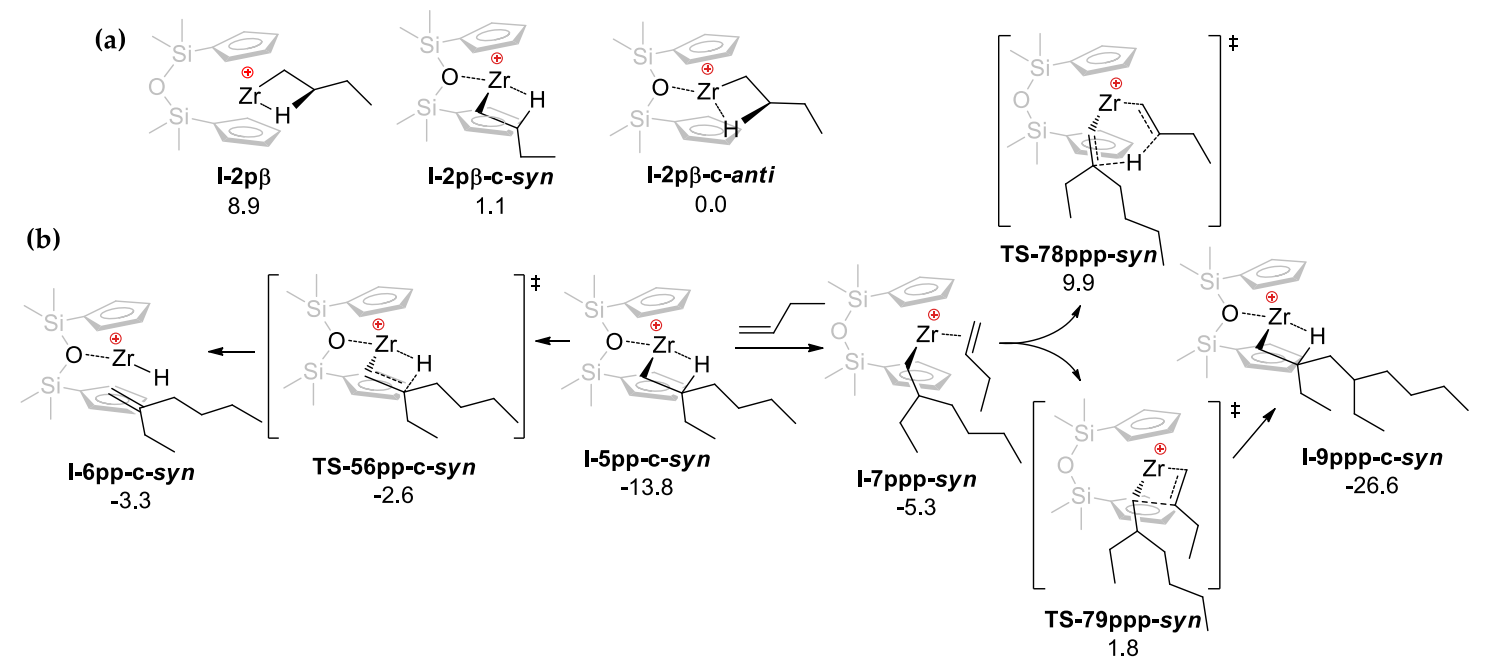

Scheme 7. Relative free energies of $\mathrm{O}\left[\mathrm{SiMe}_{2}\left(\eta^{5}-\mathrm{C}_{5} \mathrm{H}_{4}\right)\right]_{2} \mathrm{Zr}-\mathrm{Bu}$ cationic complexes (a); transformations of $\beta$-agostic complex I-5pp, the values of calculated free energies $(\mathrm{kcal} / \mathrm{mol})$ relative to $\mathbf{I}-2 \mathrm{p} \beta$-c are given (b).

To compare the impact of $\mathrm{R}_{2} \mathrm{AlX}$ on the course of oligomerization, we optimized the key stationary points and transition states involved in the transformations of branched alkyl complex I-5pp (Scheme 8). Organoaluminum fragment can occupy one of the two positions towards $\mathrm{SiMe}_{2} \mathrm{OSiMe}_{2}$ bridge and alkyl fragment, but the difference of the free energies of I-5pp-syn and I-5pp-anti was found to be $\sim 1 \mathrm{kcal} / \mathrm{mol}$. Coordination of $\mathrm{R}_{2} \mathrm{AlX}$ was energetically favorable in comparison with 1-butene even though such coordination results in the loss of $\mathrm{Zr}-\mathrm{O}$ bonding, and $\mathrm{Zr}-\mathrm{Al}_{1}$ complexes I-5pp-X were readily subjected by $\beta$-hydride elimination similarly to zirconocene 1 . The substantial difference between $\mathrm{Zr}-\mathrm{Al}_{1}$ species formed by zirconocenes $\mathbf{1}$ and $\mathbf{2}$ is in the formation of low-energy complexes I-5pp-c-X containing O-Al bond (Scheme 8) that also can eliminate the molecule of methylenealkane via 
transition states TS-56pp-c- $X$ with comparable $(X=H)$ or substantially lower $(X=\mathrm{Cl}$, only $7.4 \mathrm{kcal} / \mathrm{mol})$ activation barriers. In all cases, the coordination of $\mathrm{Me}_{2} \mathrm{AlX}$ greatly facilitates the formation of $\alpha$-olefin dimer via $\beta$-hydride elimination. However, precisely for SiOSi-bridged zirconocene and $\mathrm{X}=\mathrm{Cl}$, dual coordination of $\mathrm{R}_{2} \mathrm{AlCl}$ (Figure 4c) provides the fast dimer formation.

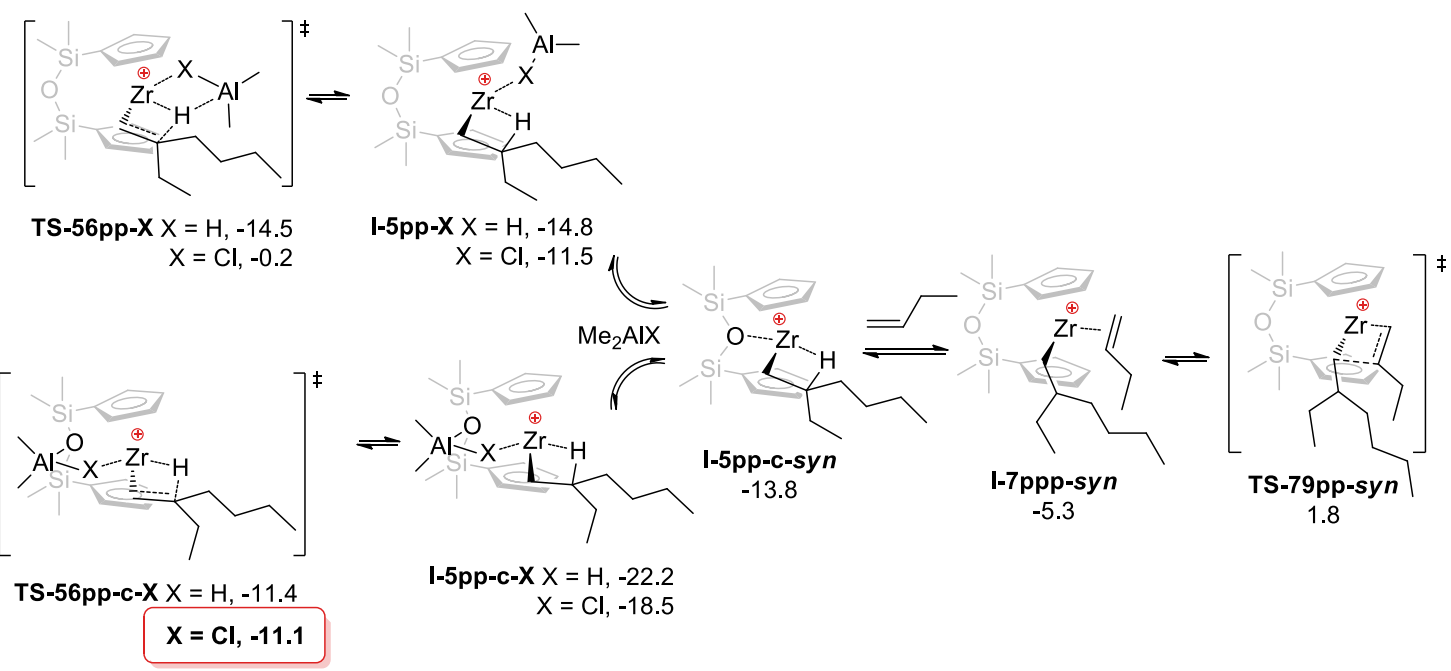

Scheme 8. Transformations of $\mathrm{O}\left[\mathrm{SiMe}_{2}\left(\eta^{5}-\mathrm{C}_{5} \mathrm{H}_{4}\right)\right]_{2} \mathrm{Zr}$-derived $\beta$-agostic complex I-5pp with the participance of $\mathrm{Me}_{2} \mathrm{AlX}$ species. The values of calculated free energies (kcal/mol) relative to I-2p $\beta-\mathrm{c}$ are given.

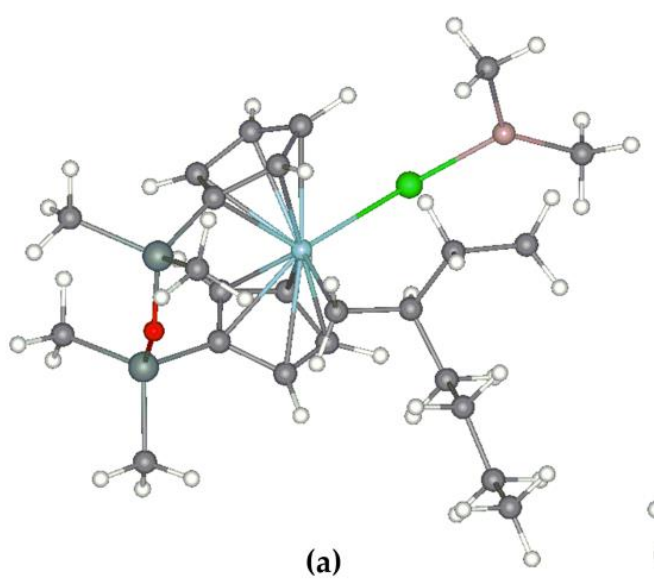

(a)

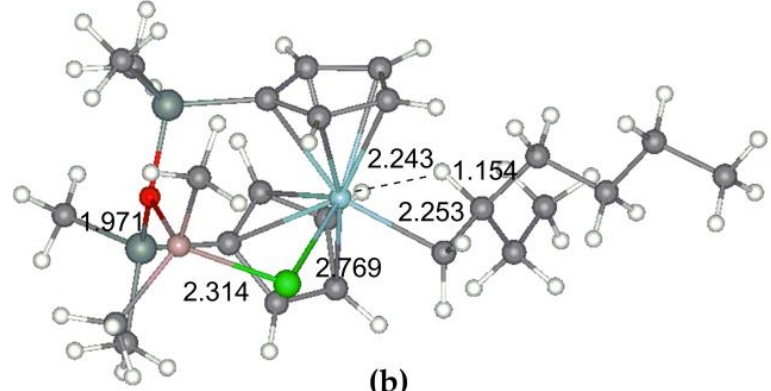

(b)

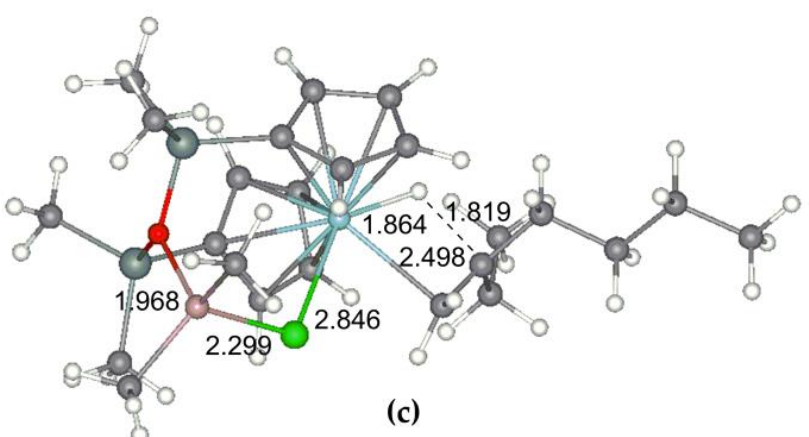

Figure 4. Optimized geometries of $\mathrm{O}\left[\mathrm{SiMe}_{2}\left(\mathrm{\eta}^{5}-\mathrm{C}_{5} \mathrm{H}_{4}\right)\right]_{2} \mathrm{Zr}$-derived stationary points I-5pp-Cl (a), I-5pp-c-Cl (b) and transition state TS-56pp-c-Cl (c).

\section{Conclusions}

Numerous theoretical studies of the polymerization mechanisms of zirconocene-catalyzed polymerization were limited by ethylene and propylene as substrates. In the present work, we refused to the use of propylene as a model of $\alpha$-olefin molecule, and 1-butene looked more adequate. In the framework of the mononuclear mechanism of zirconocene-catalyzed oligomerization, DFT modeling predicted that oligomerization is preferred over dimerization, both for $\left.\left(\eta^{5}-\mathrm{C}_{5} \mathrm{H}_{5}\right)\right]_{2} \mathrm{Zr}-\left(\mathbf{1} / \mathbf{1}^{\prime}\right)$ and 
$\mathrm{O}\left[\mathrm{SiMe}_{2}\left(\mathrm{\eta}^{5}-\mathrm{C}_{5} \mathrm{H}_{4}\right)\right]_{2} \mathrm{Zr}$-based (2/2') catalytic systems. In practice, in the absence of organoaluminum compounds, the complex $\mathbf{1}^{\prime}$ catalyzed oligomerization (although mostly producing dimer), while zirconocene $\mathbf{2}^{\prime}$ catalyzed the formation of the oligomer mixture in an equal mass ratio. These results correlate with the differences of the free energies of the isomeric transition states of chain propagation and chain release via $\beta$-hydride transfer for zirconocenes $\mathbf{1}$ and $\mathbf{2}$.

In the presence of TIBA, MMAO-12, or both organoaluminum components, the selectivity of the dimerization increased. The presence of $\mathrm{Al}-\mathrm{Cl}$ heightened the dimerization selectivity in all cases, the effect of $\mathrm{R}_{2} \mathrm{AlCl}$ was most pronounced for $\mathbf{2} / \mathbf{2}^{\prime}$. This experimental observation is consistent with the results of the modeling that predicted the facilitation of $\beta$-hydride elimination due to the $\mathrm{Zr}-\mathrm{Al}$ cooperative effect in $\mathrm{Zr}-\mathrm{Al}_{1}$ bimetallic complexes. On the other hand, for $\left.\left(\eta^{5}-\mathrm{C}_{5} \mathrm{H}_{5}\right)\right]_{2} \mathrm{Zr}$-based catalyst our calculations predicted the minimal activation barriers of the elimination for $\mathrm{Zr}-\mathrm{Al}$ hydride species. The activation barriers for chloro complexes were found to be substantially higher. We can only assume that the formation of $\mathrm{Zr}^{-} \mathrm{Al}_{1}$ hydrides is hampered by additional factors, namely by the higher stability of $\mathrm{R}_{2} \mathrm{AlH}$ dimer and trimer (see Appendix $\mathrm{A}$ ) as well as $\mathrm{Zr}-\mathrm{Al}_{2}$ trihydride complexes in comparison with chloro complexes.

The results of both oligomerization experiments and DFT calculations demonstrate the qualitative difference between $\left(\eta^{5}-\mathrm{C}_{5} \mathrm{H}_{5}\right){ }_{2} \mathrm{Zr}$ - and $\mathrm{O}\left[\mathrm{SiMe}_{2}\left(\eta^{5}-\mathrm{C}_{5} \mathrm{H}_{4}\right)\right]_{2} \mathrm{Zr}$-based catalytic systems that can be attributed to the ability of the bridged oxygen to coordinate the metal atoms, both $\mathrm{Zr}$ and $\mathrm{Al}$. Such coordination plays a crucial role in combination with $\mathrm{R}_{2} \mathrm{AlCl}$ coordination that results in dramatic lowering of the activation barrier of $\beta$-hydride elimination with a formation of methylenealkanes. SiOSi-bridged zirconocenes have long been known, but this structural aspect of their reactivity is undervalued. We expect that the -SiOSi- bridge, and potentially also -SiOR substituents in cyclopentadienyl rings, can be used in the design of novel efficient metallocene catalysts for $\alpha$-olefin oligomerization and polymerization.

Supplementary Materials: The following are available online at http:/www.mdpi.com/2073-4360/12/7/1590/s1, DFT calaulations data: plots of the molecular geometries, energies and cartesian coordinates for all stationary points and transition states mentioned in the article, Figure S1: ${ }^{1} \mathrm{H}$ NMR spectrum $\left(\mathrm{C}_{6} \mathrm{D}_{6}, 400 \mathrm{MHz}, 20^{\circ} \mathrm{C}\right)$ of $\mathbf{2}^{\prime}$, Figure S2: ${ }^{13} \mathrm{C}$ NMR spectrum $\left(\mathrm{C}_{6} \mathrm{D}_{6}, 101 \mathrm{MHz}, 20^{\circ} \mathrm{C}\right)$ of $2^{\prime}$, in pdf format.

Author Contributions: Conceptualization, I.N., A.V. (Alexander Vinogradov), and P.I.; Methodology, I.N.; Software, S.K.; Validation, A.V. (Alexander Vinogradov), A.V. (Alexey Vinogradov), and P.I.; Formal Analysis, P.I.; Investigation, A.V. (Alexander Vinogradov) and A.V. (Alexey Vinogradov); Resources, I.N.; Data Curation, P.I.; Writing-Original Draft Preparation, A.V. (Alexander Vinogradov) and P.I.; Writing-Review \& Editing, P.I.; Visualization, P.I.; Supervision, A.V. (Alexander Vinogradov); Project Administration, A.V. (Alexander Vinogradov) and I.N.; Funding Acquisition, A.V. (Alexander Vinogradov). All authors have read and agreed to the published version of the manuscript.

Funding: This research was funded by the Russian Science Foundation, grant number 18-73-10128.

Acknowledgments: This work was carried out within the State Program of TIPS RAS, in part of oligomerization experiments and analysis of the reaction mixtures.

Conflicts of Interest: The authors declare no conflict of interest. The funders had no role in the design of the study; in the collection, analyses, or interpretation of data; in the writing of the manuscript, and in the decision to publish the results.

\section{Appendix A}

The relative stability of $\mathrm{R}_{2} \mathrm{AlX}$ dimers and trimers $(\mathrm{X}=\mathrm{H}, \mathrm{Cl})$ is of direct relevance to the process of reversible and competetive bonding of $\mathrm{R}_{2} \mathrm{AlX}$ with zirconocene cations. We optimized the structures of $\mathrm{Me}_{2} \mathrm{AlX}$ monomers, dimers, and trimers and calculated the relative free energies and free enthalpies of dimer and trimer formation. The results are presented below in $\mathrm{kcal} / \mathrm{mol}$. 


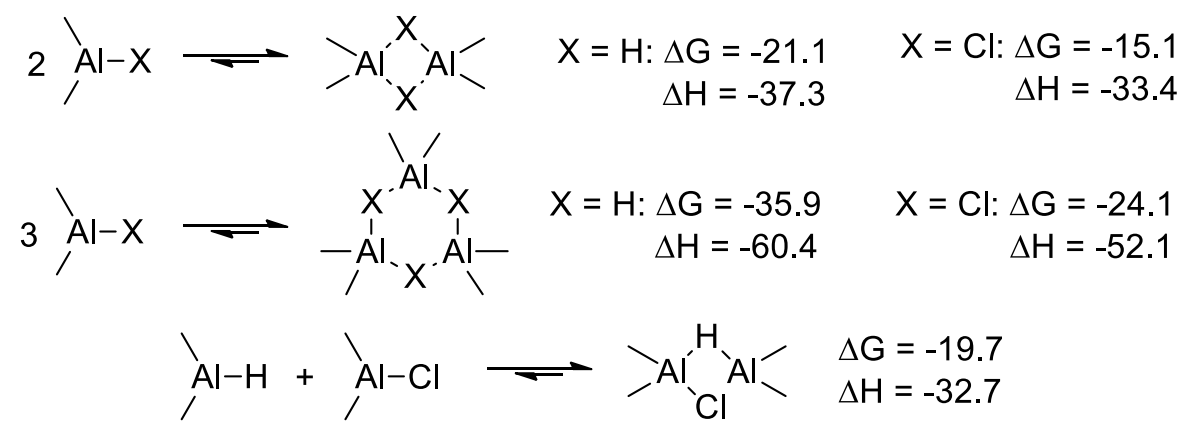

Thus, cyclic trimers of $\mathrm{R}_{2} \mathrm{AlH}$ represent the most stable species. The release of free monomeric $\mathrm{R}_{2} \mathrm{AlH}$ seems less likely than the release of monomeric $\mathrm{R}_{2} \mathrm{AlCl}$. In particular, the release of $\mathrm{Me}_{2} \mathrm{AlCl}$ in the reaction between $\mathrm{Me}_{2} \mathrm{AlH}$ dimer with $\mathrm{Me}_{2} \mathrm{Al}(\mu-\mathrm{H})(\mu-\mathrm{Cl}) \mathrm{AlMe}_{2}$, resulting in the formation of stable $\mathrm{Me}_{2} \mathrm{AlH}$ trimer, requires only $5 \mathrm{kcal} / \mathrm{mol}$ in $\mathrm{G}$ scale.

\section{References}

1. Mohring, P.C.; Coville, N.J. Group 4 metallocene polymerisation catalysts: Quantification of ring substituent steric effects. Coord. Chem. Rev. 2006, 250, 18-35. [CrossRef]

2. Chirik, P.J. Group 4 transition metal sandwich complexes: Still fresh after almost 60 years. Organometallics 2010, 29, 1500-1517. [CrossRef]

3. Brintzinger, H.H.; Fischer, D. Development of ansa-metallocene catalysts for isotactic olefin polymerization. In Polyolefins: 50 Years after Ziegler and Natta; Kaminsky, W., Ed.; Book Series Advances in Polymer Science; Springer: Berlin/Heidelberg, Germany, 2013; Volume 258, pp. 29-42. [CrossRef]

4. De Rosa, C.; Auriemma, F. Single site metallorganic polymerization catalysis as a method to probe the properties of polyolefins. Polym. Chem. 2011, 2, 2155-2168. [CrossRef]

5. Collins, R.A.; Russell, A.F.; Mountford, P. Group 4 metal complexes for homogeneous olefin polymerisation: A short tutorial review. Appl. Petrochem. Res. 2015, 5, 153-171. [CrossRef]

6. Stürzel, M.; Mihan, S.; Mülhaupt, R. From multisite polymerization catalysis to sustainable materials and all-polyolefin composites. Chem. Rev. 2016, 116, 1398-1433. [CrossRef] [PubMed]

7. Desert, X.; Carpentier, J.-F.; Kirillov, E. Quantification of active sites in single-site group 4 metal olefin polymerization catalysis. Coord. Chem. Rev. 2019, 386, 50-68. [CrossRef]

8. Castro, L.; Kirillov, E.; Miserque, O.; Welle, A.; Haspeslagh, L.; Carpentier, J.-F.; Maron, L. Are solvent and dispersion effects crucial in olefin polymerization DFT calculations? Some insights from propylene coordination and insertion reactions with group 3 and 4 metallocenes. ACS Catal. 2015, 5, 416-425. [CrossRef]

9. Desert, X.; Proutiere, F.; Welle, A.; Den Dauw, K.; Vantomme, A.; Miserque, O.; Brusson, J.-M.; Carpentier, J.-F.; Kirillov, E. Zirconocene-catalyzed polymerization of $\alpha$-olefins: When intrinsic higher activity is flawed by rapid deactivation. Organometallics 2019, 38, 2664-2673. [CrossRef]

10. Kissin, Y.V. Oligomerization reactions of 1-hexene with metallocene catalysts: Detailed data on reaction chemistry and kinetics. Mol. Catal. 2019, 463, 87-93. [CrossRef]

11. Martínez-Araya, J.I. Explaining some anomalies in catalytic activity values in some zirconocene methyl cations: Local hyper-softness. J. Phys. Chem. C 2013, 117, 24773-24786. [CrossRef]

12. Bravo, I.; Alonso-Moreno, C.; Carrillo-Hermosilla, F.; López-Solera, I.; Antiñolo, A.; Albaladejo, J. Toward the prediction of activity in the ethylene polymerisation of ansa-Bis(indenyl) zirconocenes: Effect of the stereochemistry and hydrogenation of the indenyl moiety. ChemPlusChem 2015, 80, 963-972. [CrossRef] [PubMed]

13. Falivene, L.; Cavallo, L.; Talarico, G. Buried volume analysis for propene polymerization catalysis promoted by group 4 metals: A tool for molecular mass prediction. ACS Catal. 2015, 5, 6815-6822. [CrossRef]

14. Zaccaria, F.; Cipullo, R.; Budzelaar, P.H.M.; Busico, V.; Ehm, C. Backbone rearrangement during olefin capture as the rate limiting step in molecular olefin polymerization catalysis and its effect on comonomer affinity. J. Polym. Sci. Part A Polym. Chem. 2017, 55, 2807-2814. [CrossRef] 
15. Zaccaria, F.; Ehm, C.; Budzelaar, P.H.M.; Busico, V. Accurate prediction of copolymerization statistics in molecular olefin polymerization catalysis: The role of entropic, electronic, and steric effects in catalyst comonomer affinity. ACS Catal. 2017, 7, 1512-1519. [CrossRef]

16. Parveen, R.; Cundari, T.R.; Younker, J.M.; Rodriguez, G.; McCullough, L. DFT and QSAR studies of ethylene polymerization by zirconocene catalysts. ACS Catal. 2019, 9, 9339-9349. [CrossRef]

17. Cossee, P. Ziegler-Natta catalysis I. Mechanism of polymerization of $\alpha$-olefins with Ziegler-Natta catalysts. J. Catal. 1964, 3, 80-88. [CrossRef]

18. Arlman, E.J. Ziegler-Natta catalysis II. Surface structure of layer-lattice transition metal chlorides. J. Catal. 1964, 3, 89-98. [CrossRef]

19. Arlman, E.J.; Cossee, P. Ziegler-Natta catalysis III. Stereospecific polymerization of propene with the catalyst system $\mathrm{TiCl}_{3}-\mathrm{AlEt}_{3}$. J. Catal. 1964, 3, 99-104. [CrossRef]

20. Borrelli, M.; Busico, V.; Cipullo, R.; Ronca, S.; Budzelaar, P.H.M. Selectivity of metallocene-catalyzed olefin polymerization: A combined experimental and quantum mechanical study. 1. Nonchiral bis(cyclopentadienyl) systems. Macromolecules 2002, 35, 2835-2844. [CrossRef]

21. Moscardi, G.; Resconi, L.; Cavallo, L. Propene polymerization with the isospecific, highly regioselective rac- $\mathrm{Me}_{2} \mathrm{C}(3-t-\mathrm{Bu}-1-\mathrm{Ind})_{2} \mathrm{ZrCl}_{2} / \mathrm{MAO}$ catalyst. 2. Combined DFT/MM analysis of chain propagation and chain release reactions. Organometallics 2001, 20, 1918-1931. [CrossRef]

22. Silanes, I.; Ugalde, J.M. Comparative study of various mechanisms for metallocene-catalyzed $\alpha$-olefin polymerization. Organometallics 2005, 24, 3233-3246. [CrossRef]

23. Chan, M.S.W.; Vanka, K.; Pye, C.C.; Ziegler, T. Density functional study on activation and ion-pair formation in group IV metallocene and related olefin polymerization catalysts. Organometallics 1999, 18, 4624-4636. [CrossRef]

24. Woo, T.K.; Fan, L.; Ziegler, T. A density functional study of chain growing and chain terminating steps in olefin polymerization by metallocene and constrained geometry catalysts. Organometallics 1994, 13, 2252-2261. [CrossRef]

25. Silanes, I.; Mercero, J.M.; Ugalde, J.M. Comparison of Ti, Zr, and Hf as cations for metallocene-catalyzed olefin polymerization. Organometallics 2006, 25, 4483-4490. [CrossRef]

26. Laine, A.; Linnolahti, M.; Pakkanen, T.A.; Severn, J.R.; Kokko, E.; Pakkanen, A. Comparative theoretical study on homopolymerization of $\alpha$-olefins by bis(cyclopentadienyl) zirconocene and hafnocene: Elemental propagation and termination reactions between monomers and metals. Organometallics 2010, 29, 1541-1550. [CrossRef]

27. Slaugh, L.H.; Schoenthal, G.W. Vinylidene Olefin Process. U.S. Patent 4658078, 14 April 1987.

28. Christoffers, J.; Bergman, R.G. Catalytic dimerization reactions of $\alpha$-olefins and $\alpha, \omega$-dienes with $\mathrm{Cp}_{2} \mathrm{ZrCl}_{2} /$ poly(methylalumoxane): Formation of dimers, carbocycles, and oligomers. J. Am. Chem. Soc. 1996, 118, 4715-4716. [CrossRef]

29. Christoffers, J.; Bergman, R.G. Zirconocene-alumoxane (1:1)—A catalyst for the selective dimerization of $\alpha$-olefins. Inorg. Chim. Acta 1998, 270, 20-27. [CrossRef]

30. Takeuchi, K.; Fujikawa, S. Base Oil for Oil Drilling Fluid and Oil Drilling Fluid Composition. U.S. Patent 2011251445, 13 October 2011.

31. Kissin, Y.V.; Schwab, F.C. Post-oligomerization of alpha-olefin oligomers: A route to single-component and multicomponent synthetic lubricating oils. J. Appl. Polym. Sci. 2009, 111, 273-280. [CrossRef]

32. Heilman, W.J.; Jois, Y.H.; De Kraker, A.R.; Song, W. Hydrocarbon Compositions Useful as Lubricants. U.S. Patent 2011178348, 1 May 2011.

33. Fujikawa, S.; Yokota, K.; Okano, M.; Tsuji, M. Method for producing $\alpha$-olefin oligomers and lubricating oil compositions. U.S. Patent Application 2011207977, 25 August 2011.

34. Janiak, C.; Blank, F. Metallocene catalysts for olefin oligomerization. Macromol. Symp. 2006, 236, 14-22. [CrossRef]

35. Janiak, C. Metallocene and related catalysts for olefin, alkyne and silane dimerization and oligomerization. Coord. Chem. Rev. 2006, 250, 66-94. [CrossRef]

36. Nifant'ev, I.E.; Vinogradov, A.A.; Vinogradov, A.A.; Ivchenko, P.V. Zirconocene-catalyzed dimerization of 1-hexene: Two-stage activation and structure-catalytic performance relationship. Catal. Commun. 2016, 79, 6-10. [CrossRef] 
37. Nifant'ev, I.E.; Vinogradov, A.A.; Vinogradov, A.A.; Bezzubov, S.I.; Ivchenko, P.V. Catalytic oligomerization of $\alpha$-olefins in the presence of two-stage activated zirconocene catalyst based on 6,6-dimethylfulvene 'dimer'. Mendeleev Commun. 2017, 27, 35-37. [CrossRef]

38. Nifant'ev, I.E.; Vinogradov, A.A.; Vinogradov, A.A.; Sedov, I.V.; Dorokhov, V.G.; Lyadov, A.S.; Ivchenko, P.V. Structurally uniform 1-hexene, 1-octene, and 1-decene oligomers: Zirconocene/MAO-catalyzed preparation, characterization, and prospects of their use as low-viscosity low-temperature oil base stocks. Appl. Catal. A Gen. 2018, 549, 40-50. [CrossRef]

39. Fujikawa, S.; Okamoto, T.; Yokota, K. Process for Producing Unsaturated Hydrocarbon Compound. U.S. Patent 8119850, 21 February 2012.

40. Nifant'ev, I.; Ivchenko, P.; Tavtorkin, A.; Vinogradov, A.; Vinogradov, A. Non-traditional Ziegler-Natta catalysis in $\alpha$-olefin transformations: Reaction mechanisms and product design. Pure Appl. Chem. 2017, 89, 1017-1032. [CrossRef]

41. Kissin, Y.V. Detailed kinetics of 1-hexene oligomerization reaction with ( $n$-Bu-Cp $)_{2} \mathrm{ZrCl}_{2}-\mathrm{MAO}$ catalyst. Macromol. Chem. Phys. 2009, 210, 1241-1246. [CrossRef]

42. Graeper, J.; Paolucci, G.; Fischer, R.D. Zirconocenophane dichlorides with di- and trisiloxane-bridged ring ligands: Crystal structure of rac-[1,1,3,3-tetramethyldisiloxane-diyl-bis(3-tert-butyl- $\eta^{5}$-cyclopentadienyl) zirconium(IV) dichloride. J. Organomet. Chem. 1995, 501, 211-218. [CrossRef]

43. Samuel, E.; Rausch, M.D. $\pi$-Cyclopentadienyl and $\pi$-indenyl compounds of titanium, zirconium, and hafnium containing $\sigma$-bonded organic substituents. J. Am. Chem. Soc. 1973, 95, 6263-6267. [CrossRef]

44. Laikov, D.N.; Ustynyuk, Y.A. PRIRODA-04: A quantum-chemical program suite. New possibilities in the study of molecular systems with the application of parallel computing. Russ. Chem. Bull. 2005, 54, 820-826. [CrossRef]

45. Frisch, M.J.; Trucks, G.W.; Schlegel, H.B.; Scuseria, G.E.; Robb, M.A.; Cheeseman, J.R.; Scalmani, G.; Barone, V.; Petersson, G.A.; Nakatsuji, H.; et al. Gaussian 09, Revision, A.01; Gaussian, Inc.: Wallingford, CT, USA, 2016.

46. Zhao, Y.; Truhlar, D.G. The M06 suite of density functionals for main group thermochemistry, thermochemical kinetics, noncovalent interactions, excited states, and transition elements: Two new functionals and systematic testing of four M06-class functionals and 12 other fun. Theor. Chem. Acc. 2008, 120, 215-241. [CrossRef]

47. Godbout, N.; Salahub, D.R.; Andzelm, J.; Wimmer, E. Optimization of Gaussian-type basis sets for local spin density functional calculations. Part, I. Boron through neon, optimization technique and validation. Can. J. Chem. 1992, 70, 560-571. [CrossRef]

48. Sosa, C.; Andzelm, J.; Elkin, B.C.; Wimmer, E.; Dobbs, K.D.; Dixon, D.A. A local density functional study of the structure and vibrational frequencies of molecular transition-metal compounds. J. Phys. Chem. 1992, 96, 6630-6636. [CrossRef]

49. Sun, Y.; Chen, H. Performance of density functionals for activation energies of Zr-mediated reactions. J. Chem. Theory Comput. 2013, 9, 4735-4743. [CrossRef] [PubMed]

50. Nifant'ev, I.E.; Vinogradov, A.A.; Vinogradov, A.A.; Churakov, A.V.; Bagrov, V.V.; Kashulin, I.A.; Roznyatovsky, V.A.; Grishin, Y.K.; Ivchenko, P.V. The catalytic behavior of heterocenes activated by TIBA and MMAO under a low Al/Zr ratios in 1-octene polymerization. Appl. Catal. A Gen. 2019, 571, 12-24. [CrossRef]

51. Kawahara, N.; Saito, J.; Matsuo, S.; Kaneko, H.; Matsugi, T.; Toda, Y.; Kashiwa, N. Study on unsaturated structures of polyhexene, poly(4-methylpentene) and poly(3-methylpentene) prepared with metallocene catalysts. Polymer 2007, 48, 425-428. [CrossRef]

52. Kim, I.; Zhou, J.-M.; Chung, H. Higher $\alpha$-olefin polymerizations catalyzed by rac- $\mathrm{Me}{ }_{2} \mathrm{Si}\left(1-\mathrm{C}_{5} \mathrm{H}_{2}-2-\mathrm{CH}_{3}-\right.$ $\left.4_{-}{ }^{t} \mathrm{Bu}\right)_{2} \mathrm{Zr}\left(\mathrm{NMe}_{2}\right)_{2} / \mathrm{Al}\left({ }^{\mathrm{i} B u}\right)_{3} /\left[\mathrm{Ph}_{3} \mathrm{C}\right]\left[\mathrm{B}\left(\mathrm{C}_{6} \mathrm{~F}_{5}\right)_{4}\right]$. J. Polym. Sci. Part A Polym. Chem. 2000, 38, 1687-1697. [CrossRef]

53. Babu, G.N.; Newmark, R.A.; Chien, J.C.W. Microstructure of poly(1-hexene) produced by ansa-zirconocenium catalysis. Macromolecules 1994, 27, 3383-3388. [CrossRef]

54. Grumel, V.; Brüll, R.; Pasch, H.; Raubenheimer, H.G.; Sanderson, R.; Wahner, U.M. Homopolymerization of higher 1-olefins with metallocene/MAO catalysts. Macromol. Mater. Eng. 2001, 286, 480-487. [CrossRef]

55. Babushkin, D.E.; Panchenko, V.N.; Brintzinger, H.H. Zirconium allyl complexes as participants in zirconocene-catalyzed alpha-olefin polymerizations. Angew. Chem. Int. Ed. 2014, 53, 9645-9649. [CrossRef]

56. Brant, P.; Jiang, P.; Lovell, J.; Crowther, D. Termination events in sterically hindered metallocene-catalyzed olefin oligomerizations: Vinyl chain ends in oligooctenes. Organometallics 2016, 35, 2836-2839. [CrossRef] 
57. Wu, M.M.; Pafford, B.J.; Stavens, K.B. Polyalphaolefins by Oligomerization and Isomerization. U.S. Patent application 2014323665, 30 October 2014.

58. Park, J.H.; Jang, Y.E.; Jeon, J.Y.; Go, M.J.; Lee, J.; Kim, S.K.; Lee, S.-I.; Lee, B.Y. Preparation of ansa-metallocenes for production of poly ( $\alpha$-olefin) lubricants. Dalton Trans. 2014, 43, 10132-10138. [CrossRef]

59. Wu, M.M.; Hagemeister, M.P.; Yang, N. Process to Produce Polyalphaolefins. U.S. Patent 8513478, 20 August 2013.

60. Welle, A.; Wassenaar, J.; Slawinski, M. Use of a Metallocene Catalyst to Produce a Polyalpha-Olefin. U.S. Patent 9688792, 27 June 2017.

61. Shimizu, H.; Katayama, K.; Noda, H.; Okano, M. 1-Octene, 1-decene, 1-dodecene ternary copolymer and lubricants therewith. U.S. Patent 2014256997, 11 September 2014.

62. Patil, A.O.; Bodige, S. Synthetic Libricant Basestocks and Methods of Preparation Thereof. U.S. Patent 2014046878, 23 August 2016.

63. Patil, A.O.; Bodige, S.; Luo, S.; Chu, J.W.; Stavens, K.; Harrrington, B.A. Ultra High Viscosity Synthetic Base Stocks and Process for Preparing Same. U.S. Patent 2014213834, 31 July 2014.

64. Wu, M.M.; Rucker, S.P.; Canich, A.M. Process for Producing Novel Synthetic Basestocks. U.S. Patent 9701595, 11 July 2017.

65. Nifant'ev, I.; Vinogradov, A.; Vinogradov, A.; Karchevsky, S.; Ivchenko, P. Zirconocene-catalyzed dimerization of $\alpha$-olefins: DFT modeling of the Zr-Al binuclear reaction mechanism. Molecules 2019, 24, 3565. [CrossRef] [PubMed]

66. Janiak, C.; Lange, K.C.H.; Marquardt, P. Alkyl-substituted cyclopentadienyl- and phospholyl-zirconium/MAO catalysts for propene and 1-hexene oligomerization. J. Mol. Catal. A Chem. 2002, 180, 43-58. [CrossRef]

67. Janiak, C.; Lange, K.C.H.; Marquardt, P.; Krüger, R.-P.; Hanselmann, R. Analyses of propene and 1-hexene oligomers from zirconocene/MAO catalysts-Mechanistic implications by NMR, SEC, and MALDI-TOF MS. Macromol. Chem. Phys. 2002, 203, 129-138. [CrossRef]

68. Marks, T.J.; Yang, X. Homogeneous Alpha-Olefin Dimerization Catalysts. U.S. Patent 5500398, 19 March 1996.

69. Margl, P.M.; Woo, T.K.; Ziegler, T. Potential catalyst deactivation Reaction in homogeneous Ziegler-Natta polymerization of olefins: Formation of an allyl intermediate. Organometallics 1998, 17, 4997-5002. [CrossRef]

70. Lieber, S.; Prosenc, M.-H.; Brintzinger, H.-H. Zirconocene allyl complexes: Dynamics in solution, reaction with aluminum alkyls, $\mathrm{B}\left(\mathrm{C}_{6} \mathrm{~F}_{5}\right)_{3}$-induced propene insertion, and density-functional calculations on possible formation and reaction pathways. Organometallics 2000, 19, 377-387. [CrossRef]

71. Landis, C.R.; Christianson, M.D. Metallocene-catalyzed alkene polymerization and the observation of Zr-allyls. Proc. Natl. Acad. Sci. USA 2006, 103, 15349-15354. [CrossRef] [PubMed]

72. Vatamanu, M. Synthesis, structures, and dynamic features of d0 zirconocene-allyl complexes. Organometallics 2014, 33, 3683-3694. [CrossRef]

73. Babushkin, D.E.; Panchenko, V.N.; Brintzinger, H.-H. Zirconium-allyl complexes as resting states in zirconocene-catalyzed a-olefin polymerization. Macromol. Rapid Commun. 2015, 36, 249-253. [CrossRef]

74. Vatamanu, M. Observation of zirconium allyl species formed during zirconocene-catalyzed propene polymerization and mechanistic insights. J. Catal. 2015, 323, 112-120. [CrossRef]

75. Panchenko, V.N.; Babushkin, D.E.; Bercaw, J.E.; Brintzinger, H.H. Catalyst speciation during ansa-zirconocene-catalyzed polymerization of 1-hexene studied by UV-vis spectroscopy-Formation and partial re-activation of Zr-Allyl intermediates. Polymers 2019, 11, 936. [CrossRef]

76. Götz, C.; Rau, A.; Luft, G. Ternary metallocene catalyst systems based on metallocene dichlorides and $\mathrm{AlBu}_{3}{ }^{\mathrm{i}} /\left[\mathrm{PhNMe}{ }_{2} \mathrm{H}\right]\left[\mathrm{B}\left(\mathrm{C}_{6} \mathrm{~F}_{5}\right)_{4}\right]: \mathrm{NMR}$ investigations of the influence of $\mathrm{Al} / \mathrm{Zr}$ ratios on alkylation and on formation of the precursor of the active metallocene species. J. Mol. Catal. A Chem. 2002, 174, 95-110. [CrossRef]

77. Parfenova, L.V.; Vil'danova, R.F.; Pechatkina, S.V.; Khalilov, L.M.; Dzhemilev, U.M. New effective reagent $\left[\mathrm{Cp}_{2} \mathrm{ZrH}_{2} \cdots \mathrm{ClAlEt}_{2}\right]_{2}$ for alkene hydrometallation. J. Organomet. Chem. 2007, 692, 3424-3429. [CrossRef]

78. Sizov, A.I.; Zvukova, T.M.; Belsky, V.K.; Bulychev, B.M. Aluminium zirconium $(+3$ and +4$)$ heterometallic hydrido complexes of compositions $\left[\left(\eta^{5}-\mathrm{C}_{5} \mathrm{H}_{5}\right)_{2} \mathrm{Zr}(\mu-\mathrm{H})\right]_{2}(\mu-\mathrm{H}) \mathrm{AlCl}_{2}$ and $\left[\left(\eta^{5}-\mathrm{C}_{5} \mathrm{H}_{5}\right)_{2} \mathrm{ZrH}(\mu-\mathrm{H})_{2}\right]_{3} \mathrm{Al}$. J. Organomet. Chem. 2001, 619, 36-42. [CrossRef]

79. Wehmschulte, R.J.; Power, P.P. Reaction of cyclopentadienyl zirconium derivatives with sterically encumbered arylaluminum hydrides: X-ray crystal structure of $\left(\eta^{5}-\mathrm{C}_{5} \mathrm{H}_{5}\right)_{2} \mathrm{Zr}\left(\mu^{2}-\mathrm{H}\right)_{2} \mathrm{AlC}_{6} \mathrm{H}_{2}-2,4,6-\mathrm{Bu}_{3}^{\mathrm{t}}$. Polyhedron 1999, 18, 1885-1888. [CrossRef] 
80. Babushkin, D.E.; Panchenko, V.N.; Timofeeva, M.N.; Zakharov, V.A.; Brintzinger, H.H. Novel zirconocene hydride complexes in homogeneous and in $\mathrm{SiO}_{2}$-supported olefin-polymerization catalysts modified with diisobutylaluminium hydride or triisobutylaluminum. Macromol. Chem. Phys. 2008, 209, 1210-1219. [CrossRef]

81. Parfenova, L.V.; Khalilov, L.M.; Dzhemilev, U.M. Mechanisms of reactions of organoaluminium compounds with alkenes and alkynes catalyzed by $\mathrm{Zr}$ complexes. Russ. Chem. Rev. 2012, 81, 524-548. [CrossRef]

82. Parfenova, L.V.; Balaev, A.V.; Gubaidullin, I.M.; Abzalilova, L.R.; Pechatkina, S.V.; Khalilov, L.M.; Spivak, S.I.; Dzhemilev, U.M. Kinetic model of olefin hydroalumination by $\mathrm{HAlBu}_{2}{ }_{2}$ and $\mathrm{AlBu}_{3}{ }_{3}$ in the presence of $\mathrm{Cp}_{2} \mathrm{ZrCl}_{2}$ catalyst. Int. J. Chem. Kinet. 2007, 39, 333-339. [CrossRef]

83. Parfenova, L.V.; Kovyazin, P.V.; Nifant'ev, I.E.; Khalilov, L.M.; Dzhemilev, U.M. Role of Zr,Al hydride intermediate structure and dynamics in alkene hydroalumination with $\mathrm{XAlBu}_{2}{ }_{2}(\mathrm{X}=\mathrm{H}, \mathrm{Cl}$, Bui), catalyzed by $\mathrm{Zr} \eta^{5}$ complexes. Organometallics 2015, 34, 3559-3570. [CrossRef]

84. Pankratyev, E.Y.; Tyumkina, T.V.; Parfenova, L.V.; Khalilov, L.M.; Khursan, S.L.; Dzhemilev, U.M. DFT study on mechanism of olefin hydroalumination by $\mathrm{XAlBu}_{2}{ }_{2}$ in the presence of $\mathrm{Cp}_{2} \mathrm{ZrCl}_{2}$ Catalyst. I. Simulation of intermediate formation in reaction of $\mathrm{HAlBu}_{2}{ }_{2}$ with $\mathrm{Cp}_{2} \mathrm{ZrCl}_{2}$. Organometallics 2009, 28, 968-977. [CrossRef]

85. Pankratyev, E.Y.; Tyumkina, T.V.; Parfenova, L.V.; Khalilov, L.M.; Khursan, S.L.; Dzhemilev, U.M. DFT and $\mathrm{Ab}$ initio study on mechanism of olefin hydroalumination by $\mathrm{XAlBu}{ }_{2}{ }_{2}$ in the presence of $\mathrm{Cp}_{2} \mathrm{ZrCl}_{2}$ catalyst. II. Olefin interaction with catalytically active centers. Organometallics 2011, 30, 6078-6089. [CrossRef]

86. Baldwin, S.M.; Bercaw, J.E.; Brintzinger, H.H. Alkylaluminum-complexed zirconocene hydrides: Identification of hydride-bridged species by NMR spectroscopy. J. Am. Chem. Soc. 2008, 130, 17423-17433. [CrossRef] [PubMed]

87. Parfenova, L.V.; Kovyazin, P.V.; Tyumkina, T.V.; Islamov, D.N.; Lyapina, A.R.; Karchevsky, S.G.; Ivchenko, P.V. Reactions of bimetallic $\mathrm{Zr}$, Al-hydride complexes with methylaluminoxane: NMR and DFT study. J. Organomet. Chem. 2017, 851, 30-39. [CrossRef]

88. Van der Heijden, H.; Hessen, B.; Orpen, A.G. A zwitterionic zirconocene alkyl complex as a single-component $\alpha$-olefin dimerization catalyst. J. Am. Chem. Soc. 1998, 120, 1112-1113. [CrossRef]

89. Bochmann, M.; Lancaster, S.J. Monomer-dimer equilibria in homo- and heterodinuclear cationic alkylzirconium complexes and their role in polymerization catalysis. Angew. Chem. Int. Ed. 1994, 33, 1634-1637. [CrossRef]

90. Babushkin, D.E.; Semikolenova, N.V.; Zakharov, V.A.; Talsi, E.P. Mechanism of dimethylzirconocene activation with methylaluminoxane: NMR monitoring of intermediates at high Al/Zr ratios. Macromol. Chem. Phys. 2000, 201, 558-567. [CrossRef]

91. Babushkin, D.E.; Brintzinger, H.-H. Activation of dimethyl zirconocene by methylaluminoxane (MAO)-size estimate for Me-MAO${ }^{-}$anions by pulsed field-gradient NMR. J. Am. Chem. Soc. 2002, 124, 12869-12873. [CrossRef]

92. Theurkauff, G.; Bader, M.; Marquet, N.; Bondon, A.; Roisnel, T.; Guegan, J.-P.; Amar, A.; Boucekkine, A.; Carpentier, J.-F.; Kirillov, E. Discrete ionic complexes of highly isoselective zirconocenes. solution dynamics, trimethylaluminum adducts, and implications in propylene polymerization. Organometallics 2016, 35, 258-276. [CrossRef]

93. Theurkauff, G.; Bondon, A.; Dorcet, V.; Carpentier, J.-F.; Kirillov, E. Heterobi- and -trimetallic ion pairs of zirconocene-based isoselective olefin polymerization catalysts with AlMe . Angew. Chem. Int. Ed. 2015, 54, 6343-6346. [CrossRef]

94. Ehm, C.; Cipullo, R.; Budzelaar, P.H.M.; Busico, V. Role of TMA in polymerization. Dalton Trans. 2016, 45, 6847-6855. [CrossRef]

95. Guo, Y.; He, F.; Zhang, Z.; Khan, A.; Fu, Z.; Xu, J.; Fan, Z. Influence of trimethylaluminum on kinetics of rac-Et(Ind) $\mathrm{ZrCl}_{2}$ /aluminoxane catalyzed ethylene polymerization. J. Organomet. Chem. 2016, 808, 109-116. [CrossRef]

96. Collins, S.; Linnolahti, M.; Garcia Zamora, M.; Zijlstra, H.S.; Rodríguez Hernández, M.T.; Perez-Camacho, O. Activation of $\mathrm{Cp}_{2} \mathrm{ZrX}_{2}(\mathrm{X}=\mathrm{Me}, \mathrm{Cl})$ by methylaluminoxane as studied by electrospray ionization mass spectrometry: Relationship to polymerization catalysis. Macromolecules 2017, 50, 8871-8884. [CrossRef]

97. Baldwin, S.M.; Bercaw, J.E.; Brintzinger, H.H. Cationic alkylaluminum-complexed zirconocene hydrides as participants in olefin polymerization Catalysis. J. Am. Chem. Soc. 2010, 132, 13969-13971. [CrossRef] [PubMed] 
98. Kuklin, M.S.; Hirvi, J.T.; Bochmann, M.; Linnolahti, M. Toward controlling the metallocene/methylaluminoxane-catalyzed olefin polymerization process by a computational approach. Organometallics 2015, 34, 3586-3597. [CrossRef]

99. Baldwin, S.M.; Bercaw, J.E.; Henling, L.M.; Day, M.W.; Brintzinger, H.H. Cationic alkylaluminum-complexed zirconocene hydrides: NMR-spectroscopic identification, crystallographic structure determination, and interconversion with other zirconocene cations. J. Am. Chem. Soc. 2011, 133, 1805-1813. [CrossRef]

(C) 2020 by the authors. Licensee MDPI, Basel, Switzerland. This article is an open access article distributed under the terms and conditions of the Creative Commons Attribution (CC BY) license (http://creativecommons.org/licenses/by/4.0/). 